\title{
Nature-Based Urbanization: Scan Opportunities, Determine Directions and Create Inspiring Ecologies
}

\author{
Rob Roggema ${ }^{1,2,3, *\left(\mathbb{D}, \text { Nico Tillie }^{4} \text { and Greg Keeffe }\right.}{ }^{3}$ \\ 1 Cittaideale, Office for Adaptive Design and Planning, 6706 LC Wageningen, The Netherlands \\ 2 Institute for Culture and Society, Western Sydney University, Parramatta, NSW 2150, Australia \\ 3 School of Natural and Built Environment, Queens University Belfast, Belfast BT9 5AG, Northern Ireland, UK; \\ g.keeffe@qub.ac.uk \\ 4 Urban Ecology and Ecocities Lab, Faculty of Architecture, Delft University of Technology, 2628 BL Delft, \\ The Netherlands; n.m.j.d.tillie@tudelft.nl \\ * Correspondence: rob@cittaideale.eu; Tel.: +31-615349807
}

Citation: Roggema, R.; Tillie, N.; Keeffe, G. Nature-Based

Urbanization: Scan Opportunities, Determine Directions and Create Inspiring Ecologies. Land 2021, 10, 651. https://doi.org/10.3390/ land10060651

Academic Editors: Sarel Cilliers and Elizelle Juanee Cilliers

Received: 10 May 2021

Accepted: 15 June 2021

Published: 18 June 2021

Publisher's Note: MDPI stays neutral with regard to jurisdictional claims in published maps and institutional affiliations.

Copyright: (c) 2021 by the authors. Licensee MDPI, Basel, Switzerland. This article is an open access article distributed under the terms and conditions of the Creative Commons Attribution (CC BY) license (https:// creativecommons.org/licenses/by/ $4.0 /)$.

\begin{abstract}
To base urbanization on nature, inspiring ecologies are necessary. The concept of naturebased solutions (NBS) could be helpful in achieving this goal. State of the art urban planning starts from the aim to realize a (part of) a city, not to improve natural quality or increase biodiversity. The aim of this article is to introduce a planning approach that puts the ecological landscape first, before embedding urban development. This ambition is explored using three NBS frameworks as the input for a series of design workshops, which conceived a regional plan for the Western Sydney Parklands in Australia. From these frameworks, elements were derived at three abstraction levels as the input for the design process: envisioning a long-term future (scanning the opportunities), evaluating the benefits and disadvantages, and identifying a common direction for the design (determining directions), and implementing concrete spatial cross-cutting solutions (creating inspiring ecologies), ultimately resulting in a regional landscape-based plan. The findings of this research demonstrate that, at every abstraction, a specific outcome is found: a mapped ecological landscape showing the options for urbanization, formulating a food-forest strategy as the commonly found direction for the design, and a regional plan that builds from the landscape ecologies adding layers of productive ecologies and urban synergies. By using NBS-frameworks, the potentials of putting the ecological landscape first in the planning process is illuminated, and urbanization can become resilient and nature-inclusive. Future research should emphasize the balance that should be established between the NBS-frameworks and the design approach, as an overly technocratic and all-encompassing framework prevents the freedom of thought that is needed to come to fruitful design propositions.
\end{abstract}

Keywords: food forestry; landscape first; nature-driven urbanism; nature-based solutions; research by design; Western Sydney

\section{Introduction}

Global biodiversity is declining at a worrisome rate [1]. For instance, in the Netherlands, biodiversity has strongly declined during the last century [2]. Despite a range of efforts, this decline is difficult to counteract, especially for vulnerable species [3]. In the Netherlands, biodiversity, measured by the quality and quantity of nature, has reduced to approximately $15 \%$ of its original state. Loss of biodiversity due to agricultural activities and urbanization is the major reason behind the building up of biodiversity loss [4]. The way humans exploit the earth has grown to such an extent that a whole new geological era was defined by it: the Anthropocene [5]. Urbanization and the ongoing growth of cities induce large-scale conversion of rural to urban landscapes, threatening ecosystems [6]. There is a direct relationship between the way cities are developed and the negative influence this has on the ecological quality of the environment. Current practice is hard to alter and, where existing urban planning focuses on the developments, trends, and habits applied 
in the recent past, it seems to be repeating how policies responded to former experiences, thus formulating copies of policies for novel or unknown problems of the future $[7,8]$. Simultaneously, alternative planning theories have been analyzed using literature reviews that focus on planning theory, which separates out high and low dynamic land-uses, such as casco-planning [9] and the strategy of the two networks [10,11]. This brought the changeability of urban layers to the fore [12]. Despite the fact that these alternative planning frameworks have been studied for decades, their implementation, use in, and impact on the transformation of urban development have been minimal. Green-blue systems, structures, and spaces are recognized for their capacity to conserve biodiversity [13,14], lead to environmental, economic, and social benefits $[15,16]$, and can play an essential role in mitigating and adapting to climate change [17]. Therefore, nature-based solutions (NBS) have the means to not only support ecosystems, but also to redefine urban development approaches. In this article, a design-led way to integrate ecological principles in urban planning is explored by making use of NBS frameworks.

The term 'nature-based solutions' (NBS) was coined by the European Union and is an umbrella term for a number of different approaches that use nature to improve urban resilience, like green infrastructure, green space, restoring rivers, ecosystem services, and ecosystem-based adaptation [18]. In the EU research and innovation policy agenda [17] the following description is given: "Nature-based solutions aim to help societies address a variety of environmental, social and economic challenges in sustainable ways. They are actions inspired by, supported by or copied from nature; both using and enhancing existing solutions to challenges, as well as exploring more novel solutions, for example, mimicking how non-human organisms and communities cope with environmental extremes. Naturebased solutions use the features and complex system processes of nature, such as its ability to store carbon and regulate water flows, to achieve desired outcomes, such as reduced disaster risk and an environment that improves human well-being and socially inclusive green growth. This implies that maintaining and enhancing natural capital is of crucial importance, as it forms the basis for solutions. These nature-based solutions ideally are resilient to change, as well as energy and resource efficient, but to achieve these criteria, they must be adapted to local conditions". In short, the European Commission defines NBS as [19]: "solutions that are inspired and supported by nature, which are cost-effective, simultaneously provide environmental, social and economic benefits and help build resilience. Such solutions bring more, and more diverse, nature and natural features and processes into cities, landscapes and seascapes, through locally adapted, resource-efficient and systemic interventions".

The International Union for the Conservation of Nature defines NBS as [20]: "actions to protect, sustainably manage, and restore natural or modified ecosystems, that address societal challenges effectively and adaptively, simultaneously providing human well-being and biodiversity benefits". These solutions:

1. Embrace nature conservation norms (and principles);

2. Can be implemented alone or in an integrated manner with other solutions to societal challenges (e.g. technological and engineering solutions);

3. Are determined by site-specific natural and cultural contexts that include traditional, local, and scientific knowledge;

4. Produce societal benefits in a fair and equitable way, in a manner that promotes transparency and broad participation;

5. Maintain biological and cultural diversity and the ability of ecosystems to evolve over time;

6. Are applied at a landscape scale;

7. Recognize and address the trade-offs between the production of a few immediate economic benefits for development, and future options to produce the full range of ecosystems services;

8. Form an integral part of the overall design of policies, and measures or actions to address a specific challenge. 
Hence, NBS are seen as deliberate interventions seeking to use the properties of nature to address societal challenges.

NBS have illuminated a substantial potential to respond to climate change [21,22], to adapt to climate change impacts [23-25], and to create co-benefits in urban areas. In this way, NBS are well placed to accelerate urban transitions and create additional and multiple health $[26,27]$ and social [28] benefits, such as equity, fairness, and justice. The uptake in governance and policy arenas $[29,30]$ are seen as conditional for their success. NBS are seen as a more efficient and cost-effective approach to design resilient landscapes and cities that turn out to be economically viable and reach beneficial social and environmental outcomes [31]. The implementation of NBS in cities, however, still requires significant attention to be aesthetically appealing to citizens, create new green urban commons, create trust in local government and the process of experimentation, secure diversity and social innovation, be collaborative, develop an inclusive narrative, and develop design that can be replicated in the long-term [32]. Therefore, "urban planners need to have an open approach to collaborative governance of nature-based solutions that allows learning with and about new appealing designs, perceptions and images of nature from different urban actors, allows forming of new institutions for operating and maintaining nature-based solutions to ensure inclusivity, livability and resilience" [32]. Furthermore, the importance of collaborative research is acknowledged as a successful way researchers and practitioners iteratively learn from coproducing knowledge using holistic, integrative approaches and systematizing how multiple types of data and knowledge can be smartly used to plan for adaptation and mitigation [33].

The all-encompassing meaning of NBS asks for an overarching concept, bringing the diversity of directions together in the form of nature-based thinking, to use "inspiration by nature as an outset for the development of more sustainable and inclusive cities, balancing anthropocentric and eco-centric values and acknowledging the importance of the social and governance dimensions in a more balanced socio-ecological perspective" [34]. The design of NBS is seen as one of the knowledge gaps requiring further investigation in how design knowledge and skills can be used to create multifunctional, environmental, and social urban environments [35]. In this context, the impact of design approaches to nature-based and nature-driven urbanism [36,37] could play an important role in discovering the benefits of integrative and future-oriented creative ways of thinking to overcome well-known barriers preventing implementation and upscaling of NBS, such as the fear of the unknowns, the disconnect between short-term actions and long-term goals, the discontinuity between short-term actions and long-term plans, sectoral silos, and the paradigm of growth [35].

This article begins by describing the context of the case study area, current approaches, and related problems to urban planning and design, and identifies three useful NBS frameworks for a design-led approach. In Section 3, the research problem and objective are formulated, followed by the methodology and research design. Section 5 presents the research findings, and the article is concluded with the discussion and conclusions.

\section{Background}

\subsection{Case Study Area}

The metropolitan area of Sydney is expected to grow from approximately five to over seven million people in the next 20 years [38]. Where new housing will be located and what supporting infrastructure are required is a major question that needs to be answered at the larger scale. The Greater Sydney Commission has therefore developed a long-term spatial strategy, dividing the total area as three complementary cities [39]. The majority of new housing is, in this strategy, planned in the so-called third city of the Western Sydney Parklands (Figure 1). 


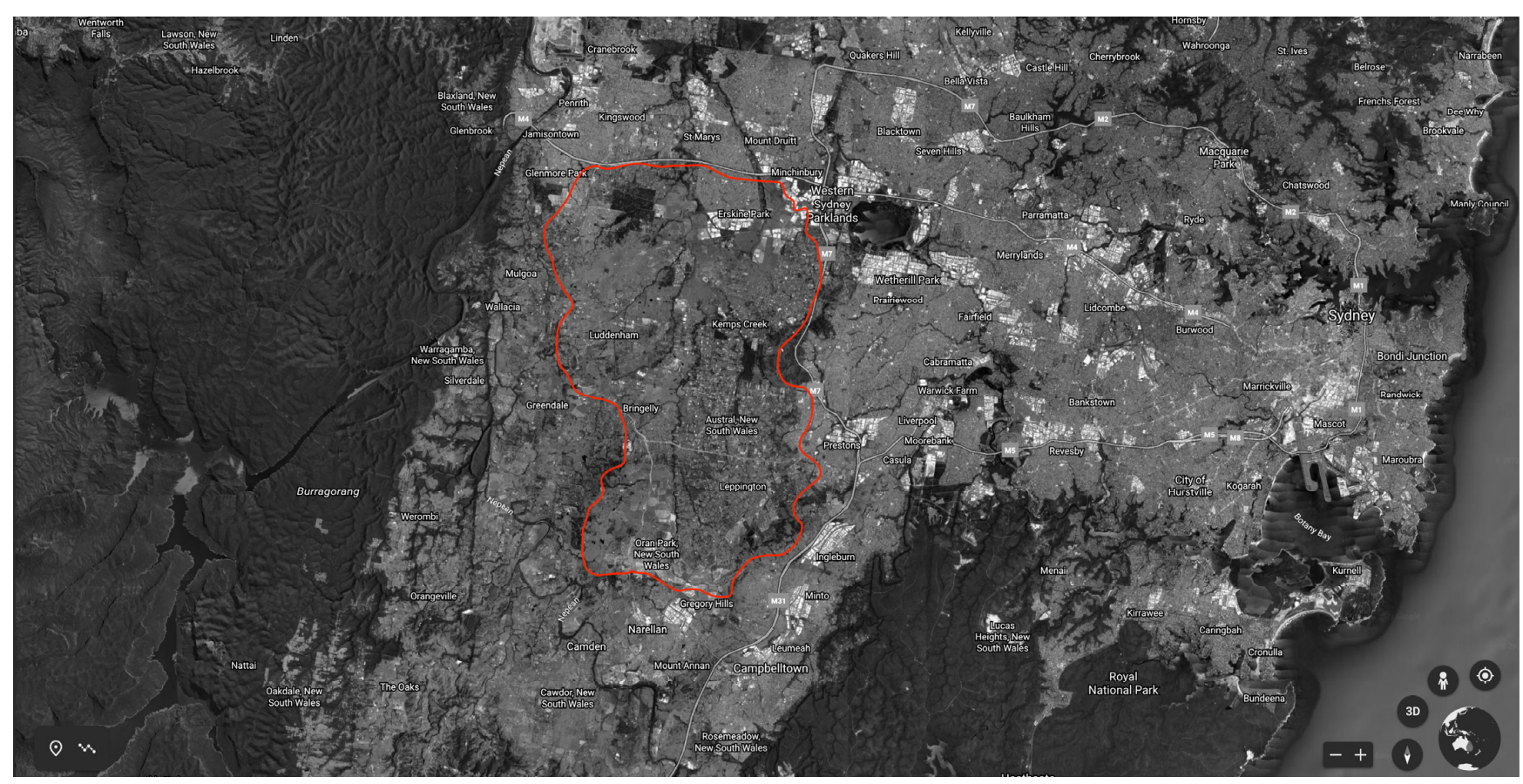

Figure 1. Western Sydney Parklands study site.

The Western Sydney City Deal formulates, as its main ambitions to deliver, around the anticipated Western Sydney airport, "a 30-minute city by delivering the North-South rail link, create 200,000 jobs capitalizing on the new Aerotropolis and the new agribusiness district, skilling residents in the region, respecting and building local character through a livability program, and coordinate and innovate through a planning partnership, continuing to consist of all three levels of government" [40]. This area will be home to over one million new residents and therefore requires a large-scale urban plan in which future resilience is the condition for newly built homes.

The Cumberland Plain landscape [41] is vulnerable to development due to its high ecological and aboriginal values, susceptibility to heat (with highs of $45^{\circ} \mathrm{C}$ in summer), droughts (due to prolonged heat and low precipitation in summer), and flooding (up to nine meters of flooding during heavy rain and the rapid discharge of rainwater through the confined creek systems), and the risk of bushfires in times of strong western-northwestern winds combined with high temperatures [42]. The landscape is hilly, and the ground is fertile with semi-open vegetation and shrubs, and it is used as sparse or dense cattle fields and for chicken and mushroom farming. In this area a new airport is planned, surrounded by a so-called aerotropolis, consisting of logistics and agribusiness, with one million new residents, predicted to be living in approximately 350,000 new homes. The infrastructure consists of new trainlines connecting the new precinct with the existing urban area, bus connections, light-rail trams, and a new automobile grid with freeways and tangential roads.

If the development process is driven by the path-dependency connected to former urban typologies of urban sprawl, a vast sea of houses for one million people would result in overthrowing the current qualities and values, but also introduce a higher risk of bushfires, water scarcity, and water burden when it rains [43]. This context of rapid urbanization, in combination with a vulnerable landscape and climatic changes, makes this area an interesting research subject. Moreover, the way resources are generated, used, and related to each other is an essential feature of future urban design planning [44]. Finally, the local stakeholders and decision-makers have shown great interest in developing such a large-size urban area in the most resilient and sustainable way, taking its ecosystems as the base for their thinking. 
A city that is in balance with nature and ecology, inclusive of green infrastructure [45,46], and urban ecology [47-49] is often constrained by neoliberal urbanism [50,51], in which market forces dominate the outcomes [52]. Despite the fact that consumers have often declared their desire to reside in green environments [53,54], developers and builders seem to follow their own market analyses which indicate that consumers demand the largest homes for the lowest prices [55-57]. While this is a generalization, the dominance of urban growth has long been characterized by fulfilling short-term needs and fast responses to housing demand [38]. When an ecological urban development is prioritized, a long-term urban plan is the only way forward. In current practice, it is very difficult to develop such a long-term spatial strategy that is consistent for a longer period. Instead, ad-hoc urbanism, driven by landownership, short term profits, a housing market under pressure, and a quick development process, prevails, leading to an ever-continuing sprawl of new housing [58-60].

\subsection{Current Urban Development}

Recent urban development in the Sydney metropolitan area has been characterized by this market-driven pressure and has led to the building of homes of maximized size on the plot they are built on, with black, heat-absorbing roofs, and built according the 4-2-2-concept: four bedrooms, two bathrooms, and a double garage [61]. In the urban design, the location of the station at the center of the area and surrounded by all amenities, offices and multilevel, multifunctional buildings, determines the lay-out of the neighborhood. The dogma to house most people within a radius of $500 \mathrm{~m}$ from the station, means the highest densities are found here and housing is planned in a convenient grid $(80 \times 40 \mathrm{~m}$ or $80 \times 80 \mathrm{~m}$ ) further away. Waterways and riparian zones are seen as an obstructive stand in the way of more housing, which are often built in low densities with their back to these green zones. This business-as-usual urbanization model [62], represented by one recent example of urban planning for the Austral-Leppington area in Sydney's west (Figure 2), is based on these urban planning principles:

1. A circle around the station and bus stop determines higher densities (in blue and dark orange);

2. Outside the public transport corridors, other land-use, such as low-density housing and green space, is located far from high densities;

3. The road system is designed to form an efficient grid;

4. Waterways are the spaces that remain after the station, density, and road system are planned. Here, at a distance from the station, low-density housing is planned and is only accessible by car.

The consequence of this is that in many urban plans, the landscape has become the backyard of the city instead of an amenity for enhancing the quality of life and the value of real estate. Moreover, these potential qualities are only available for a limited group of residents: those privileged enough to have their backyard border onto these water and riparian zones. 


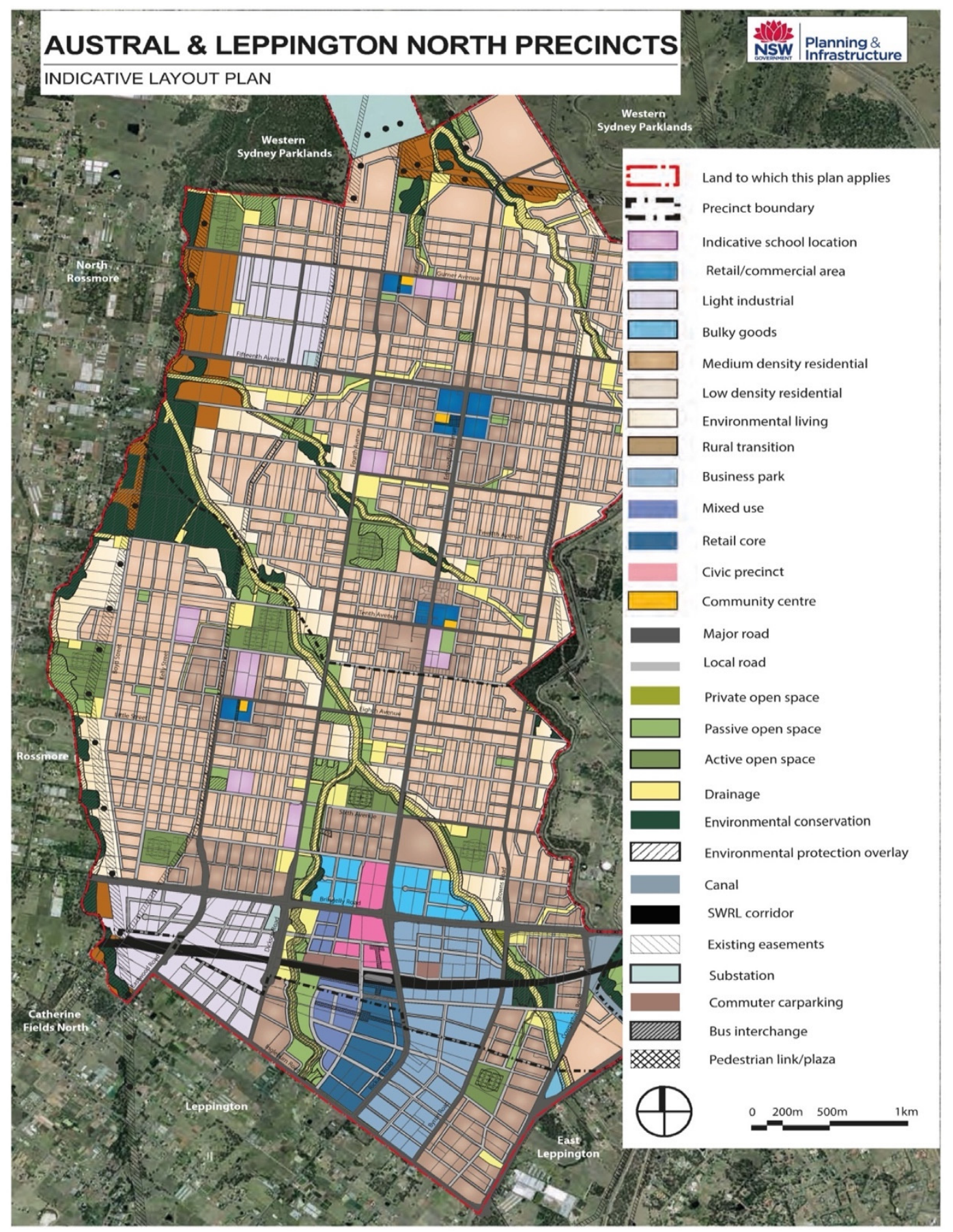

Figure 2. Recent plan for the Western Sydney area: the plan for Austral \& Leppington [62].

Current urban development seems to underestimate the consequences for increasing the vulnerability of its future residents, sidelining the potential of green infrastructure to create a healthy urban environment, both for urban ecology [47-49] and physical [63] and mental [64-67] human wellbeing. Under current market stress this form of urban development will, most likely, continue, resulting in a new phase of urban sprawl in the westerns fringe of the Sydney metropolitan area, most probably in the form of a sea of similar houses in identical neighborhoods (Figure 3). The vast area will be filled up with housing similar to the Austral-Leppington plan. Figure 3 shows the future of such a landscape, in the form of a redesign of the region, copying the current planning principles as a montage. 


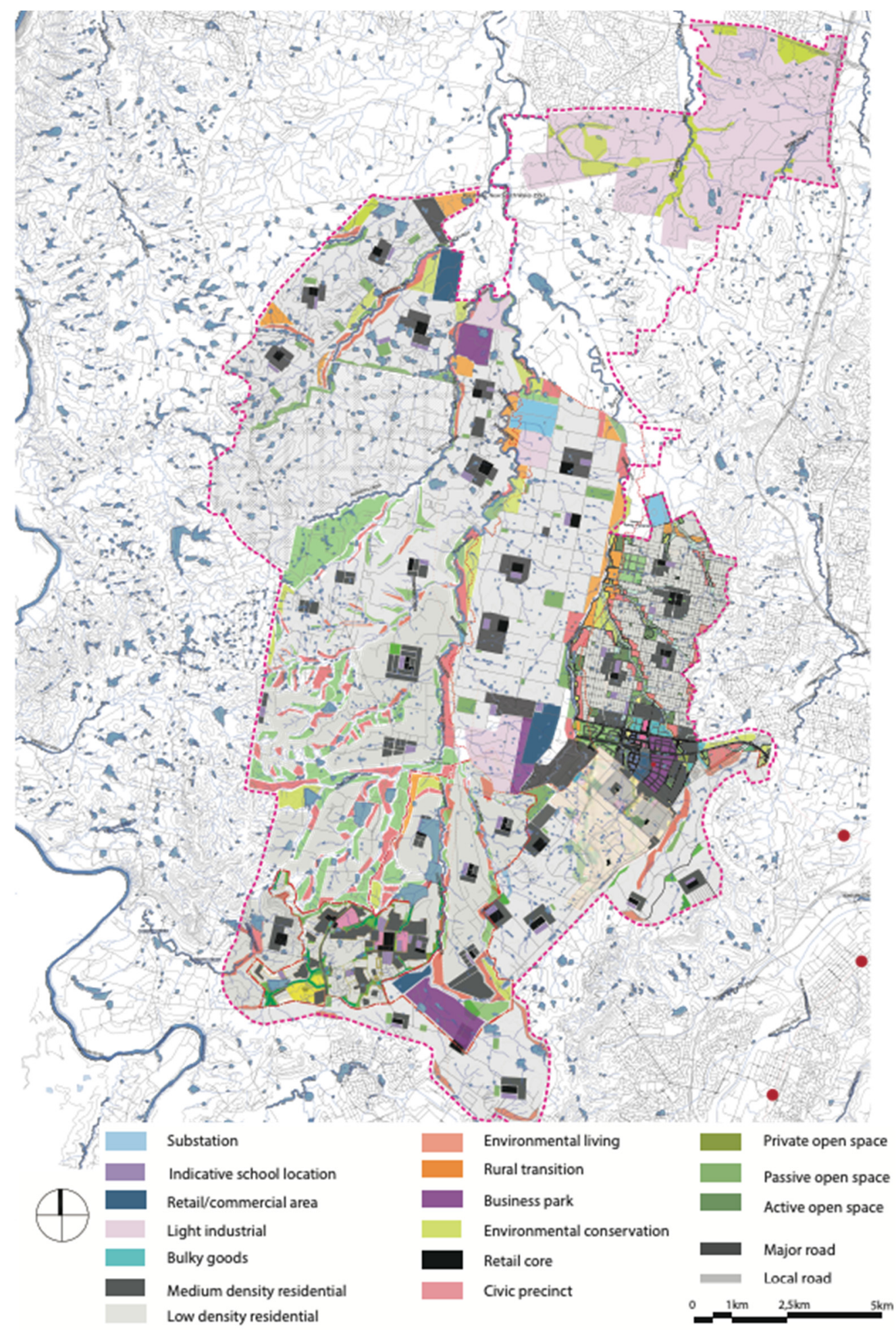

Figure 3. Copy and pasting of the Austral plan leads to continuous urban sprawl [68].

\subsection{NBS Frameworks}

To counteract a thoughtless replication of recent urban planning and providing the directives to apply NBS, three major frameworks were used to guide this research.

In the first framework (Figure 4), NBS for climate-proofing, three phases are distinguished [69]. The initial phase, visioning and backcasting, describes the vision for a climate-proof future and the concrete actions to make this vision a reality. In the second stage, the benefits and costs of the vision and its actions are evaluated, and a preferred 
alternative is chosen. The final step contains the implementation and management of this solution. In three steps, the framework (1) identifies, (2) evaluates, and (3) implements.

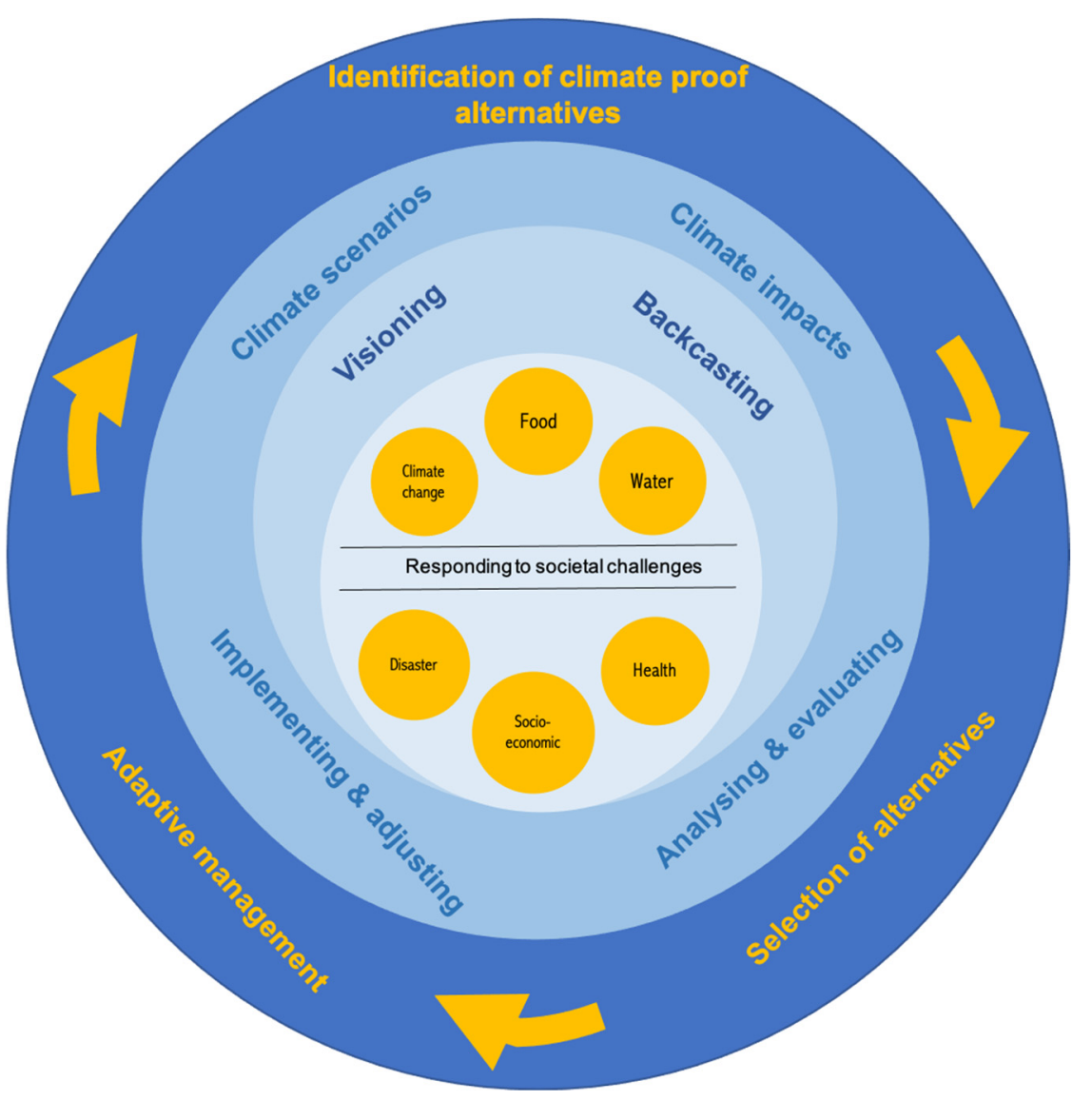

Figure 4. Assessment framework for climate-proof NBS (adapted from: [69]).

The second framework, shown in Figure 5, the co-benefits of NBS [70], consists of three layers. In the first, broadest layer, four system dimensions are defined: the socio-cultural and economic system, biodiversity, ecosystems, and climate. These systems are interlinked with the benefits for human health, environmental performance, synergies to biodiversity, and potential for citizen involvement [35]. The second layer identifies 10 societal challenges faced by cities in light of global environmental change. The third layer, at the heart of the model, integrates these subjects into a holistic approach, enabling cross-cutting solutions to design NBS by understanding the environmental and socio-ecological context, addressing multiple interconnected challenges, implementation across multiple scales, and using multiactor co-production processes over the long-term [70]. This framework entails thinking at system, subject, and solution levels. 


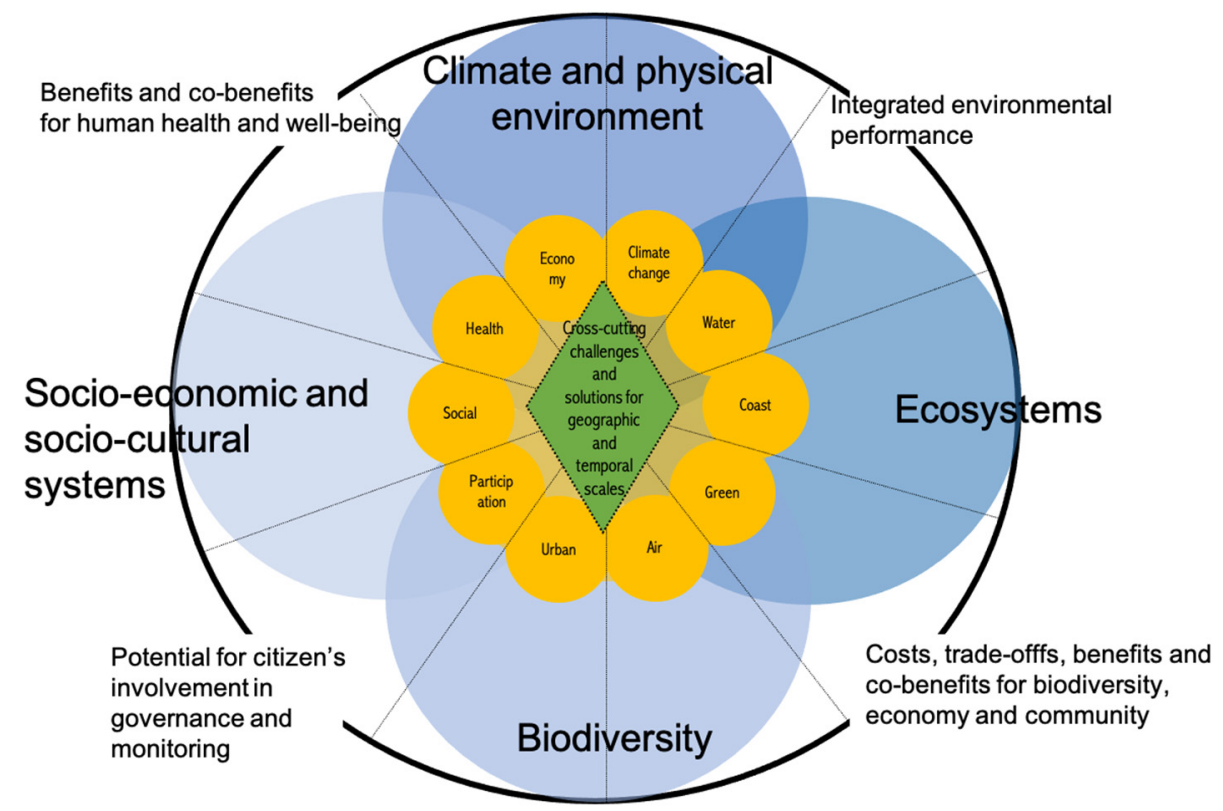

Figure 5. Assessment framework for co-benefits of NBS (adapted from: [70]).

The third framework (Figure 6), NBS-typologies, introduces three types of NBSsolutions. The first type of solutions enables better use and management of existing natural ecosystems. The solutions belonging to type two aim to restore ecosystems, and the third type of solutions aim to create novel ecosystems [71]. In short, these three types can be characterized as managing, restoring or recreating ecosystems for land and water environments when applied to cities or urban regions.

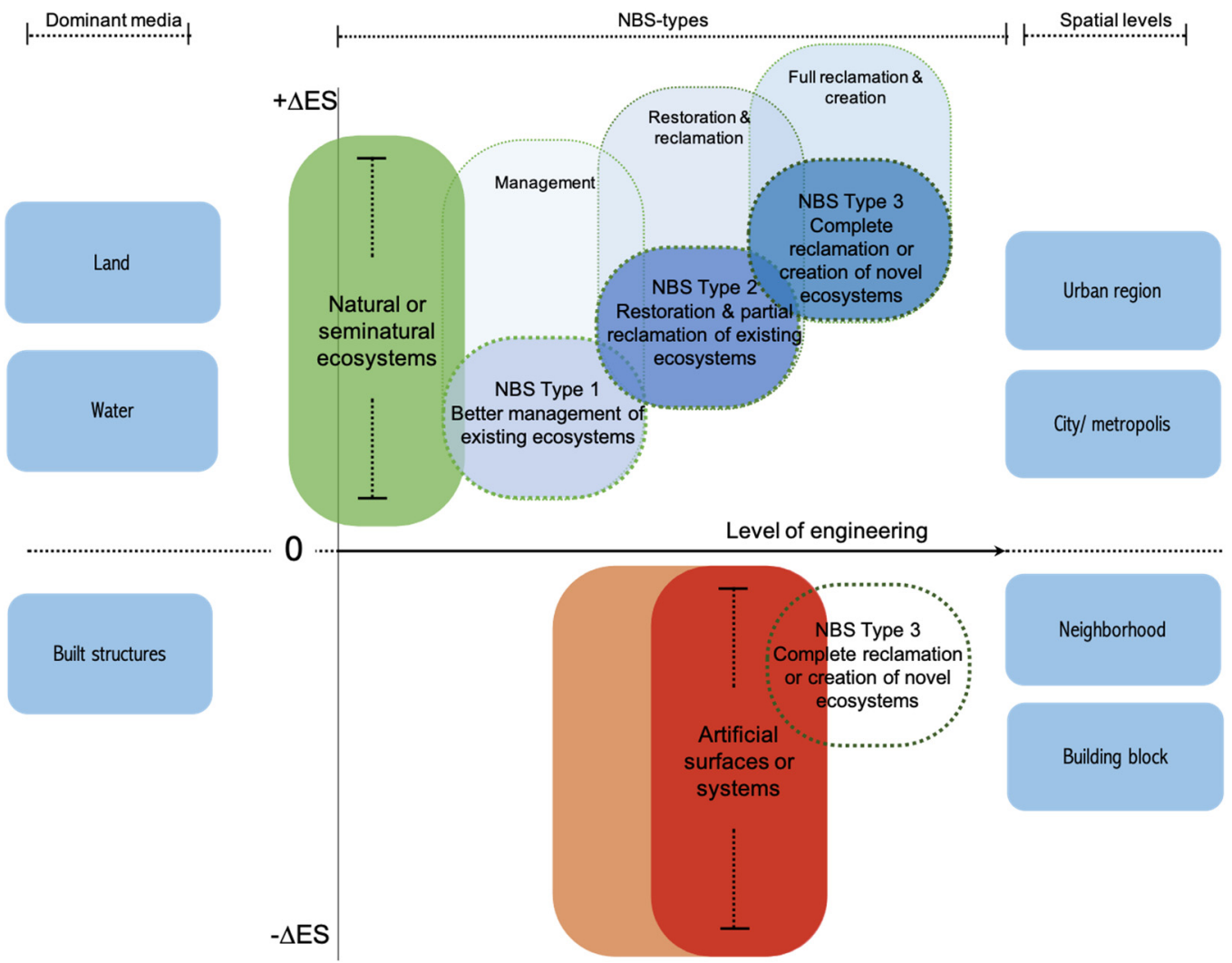

Figure 6. Conceptualization of NBS-types (adapted from: [71], based on [20,72]). 


\section{Research Problem and Objective}

In most urban planning cases, at least in the Australian context [73], current urban development practices start with urban development. While this is obvious, an alternative practice is yet to unfold. As mentioned before, the way cities are planned cause serious problems for human as well as non-human lives. Climate impacts, loss of biodiversity, social and health implications, and depletion of resources, are all, to a larger or lesser extent, caused by urbanization. The market-driven way of exploitation of new neighborhoods, such as in the Sydney metropolitan region, accelerates these problems. In practice, ecosystems, biodiversity, natural water systems, and green space for recreational purposes are seen as additions to the core of planning, which consists of housing and infrastructure. This is a missed opportunity and disciplines, such as landscape architecture, urban planning and design, should use their profession to create resilient cities. The urban fabric is all too often the end to which green infill is added (Figure 7, left).

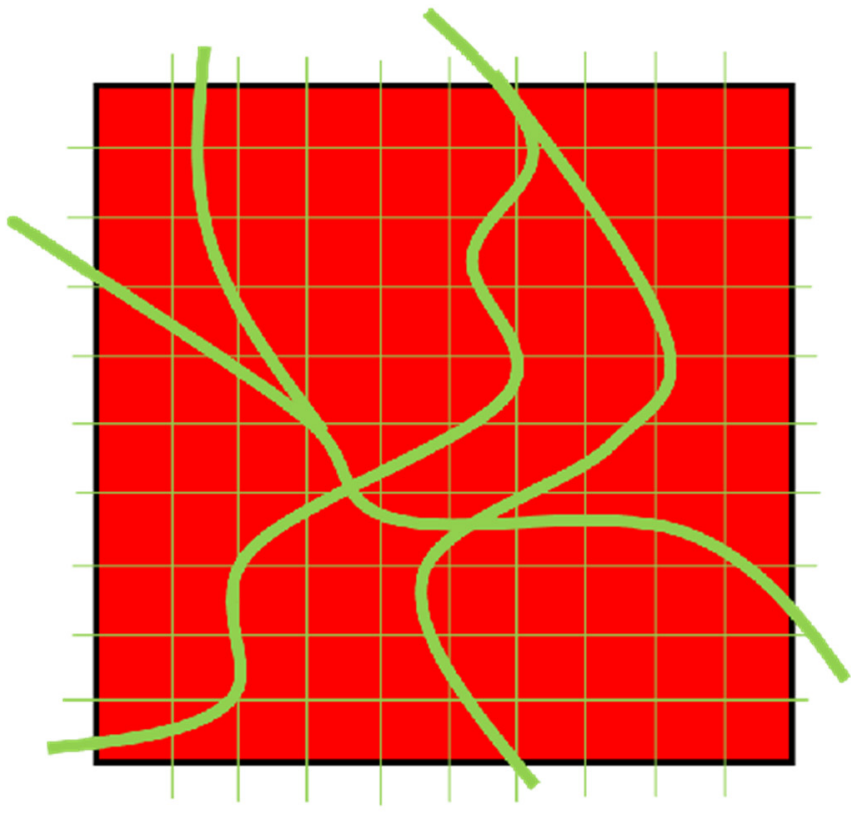

Urban Development - Natural infill

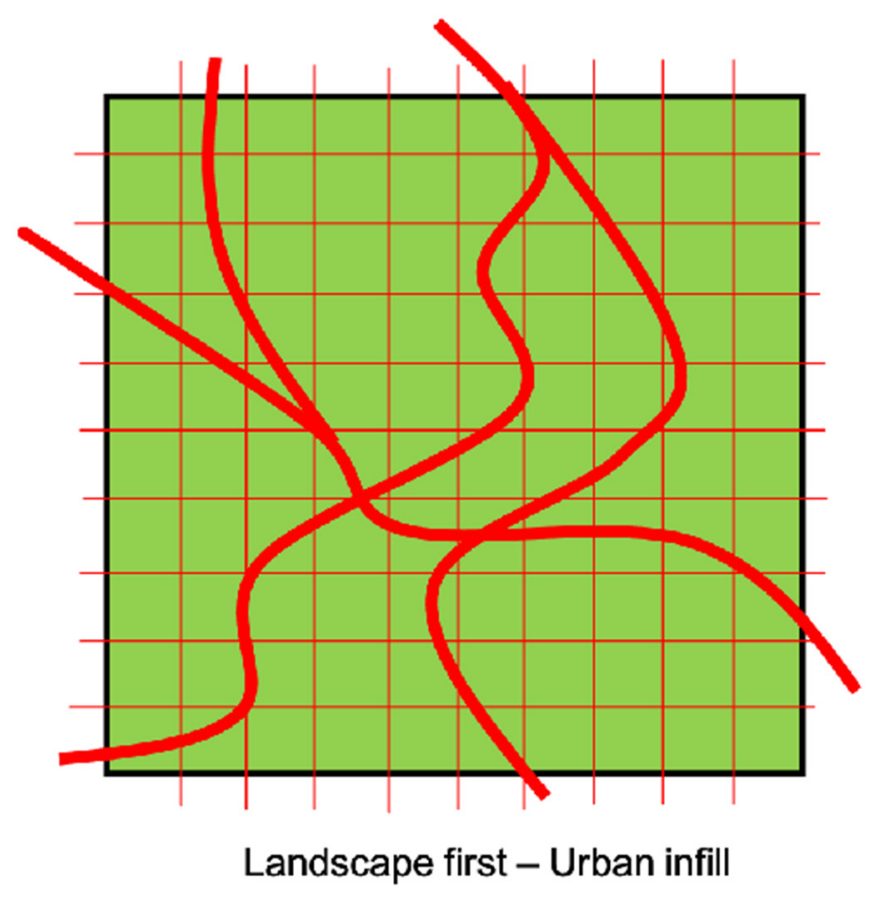

Figure 7. From (right) current practice in urban development towards (left) landscape-driven planning (by the authors).

Therefore, our research objective is to investigate how NBS can use these solutions to design the landscape system before urban functions are embedded within the features and vulnerabilities of the landscape. This takes landscape urbanism principles, well-known for a long time [74-76], as the basis of the design. The main shift is not so much to use the theory and methodology of landscape urbanism, but to implement it. This would imply a transition from a process that takes housing and the urban program as the start and adding green spaces as an amenity at a later stage (Figure 7, left), towards establishing the qualities of the landscape first, which then determine the way urban infill can be adopted (Figure 7, right).

\section{Methodology and Research Design}

In the methodology, abstractions of the three frameworks were used to guide design workshops. Taking these frameworks as the point of departure acknowledges the role NBS is expected to play in the design process, as a prime starter of the spatial propositions to follow. Each of the frameworks thus provide input in three consecutive stages of design (Figure 8), starting at the highest abstraction levels, then zooming in to concrete levels of thought. The design workshops are guided to be interactive and iterative to guarantee that the findings of each workshop will act as the foundations for the workshops to follow. The 
workshops themselves use an action research method [77-79], in which the researchers are participants of the design workshops. Each of the following steps in the research process are shaped using research by design principles [80-85] through which intermediate results can be constantly assessed and valued [86].

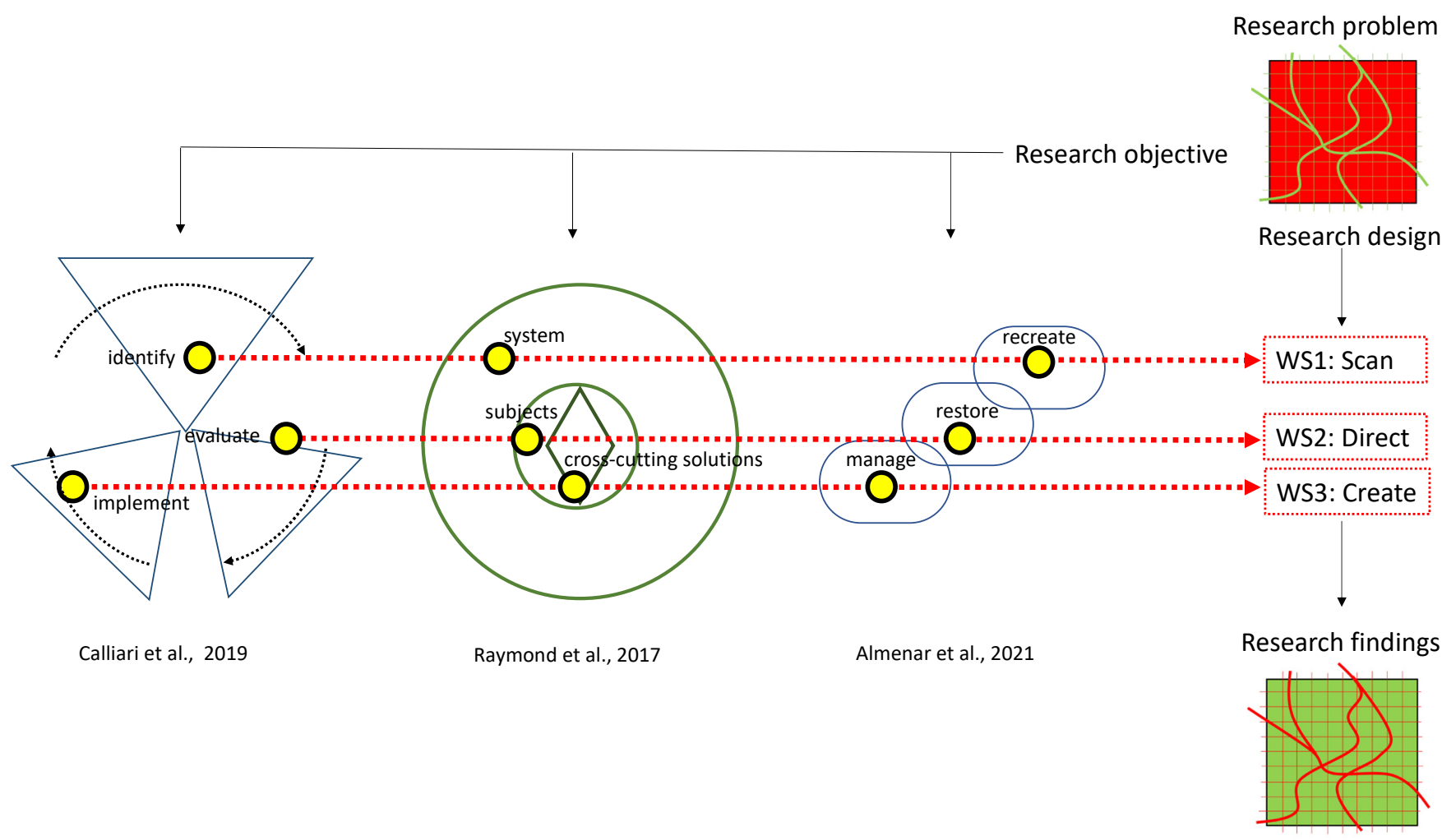

Figure 8. Methodology (by the authors).

In three consecutive design workshops, which took place between April and November 2019 and used the design charrette method [87-90], novel concepts and ideas were explored by allowing individual ideas to emerge and synergize into the overarching objectives and concepts. The design workshops consisted of a combination of work, such as spatial analyses, mapping exercises, collaborative design, conceiving of spatial propositions, and the building of plasticine models, each used in a specific context, timing, and appropriation. Since the objective of this research was to alter the urbanism approach from an urban development point of view to a nature-driven perspective, each of the conducted workshops started from an ecological point of view. In workshop one, the focus lay on scanning opportunities at the highest abstract level (why), in the second workshop, concepts were evaluated and one visionary direction was chosen (what), and, finally, during the third workshop, this vision was designed in greater detail (how).

\subsection{Workshop 1: Scanning Opportunities-Identify, System, Recreate}

In the first workshop, organized in Parramatta, NSW, Australia, a total of 50 participants took part, including representatives of the regional and state government, the utility sector, local councils, community groups, researchers from four local universities, professional designers and consultants, and organizational change managers. The professional background of the participants was broad and included landscape architects, urban and regional planners, ecologists, agronomists, sustainability experts, water system specialists, environmentalists, policy and public administration professionals, energy experts, students, and local citizens. The researchers took on different roles in the lead up to, during, and after the workshop. They designed the process, facilitated the workshop, participated 
as designers, conducted the analytical mapping beforehand, reported on, and illustrated the results.

From the NBS frameworks introduced before, the aspects identify, systems and recreate (see Figure 8) were used as the input for the first workshop. The major problems, such as climate change and impacts, degradation of the land, flood risk, social divide, food system, transportation, eco- and water systems, socio-economics, citizen engagement, and their social habitat, were identified and scoping of their future potentials was undertaken in the form of exploratory scenarios. During the workshop, special attention was given to ways novel ecosystems could be recreated, fitting with the historic qualities of the Cumberland Plain [91]. To interlink spatial scales, analytical mapping was conducted before the start of the workshop, which gave layered information on the potential direction for future urban planning.

At this stage of envisioning the future, creative methods, such as the art of the longterm view [92], futuring [93,94], and spatial visioning [95,96], were applied. Focusing on the long-term while making choices in the present requires a method that fits the long- and short-term simultaneously, and, thus, the backtracking method was used [97] to make this process tangible. Additionally, an exploration of involved stakeholders and residents was undertaken, using the method of actor-network mapping [98,99] and assemblage [100-102].

\subsection{Workshop 2: Determine Directions-Evaluate, Subject, Restore}

The second workshop, also organized and held in Parramatta, was attended by 35 participants. The typology of participants, their professional backgrounds, and the roles of the researchers were very similar to the first workshop. The concepts derived from the NBS frameworks, evaluate, the subjects, and restoration (see Figure 8), formed an additional set as the input for the sessions. The second workshop started with evaluating the analytical mapping work on the potentials, impacts and problems of the regional ecosystems, and the high-level vision, determined in the first workshop, on how urban developments could be embedded in the landscape. The benefits, associated problems, and implications for the four distinguished systems (socio-economic, ecosystems, biodiversity, and physical) were tested against each of the relevant subjects in this area (green, water, climate, food, participation, health, air, urban social, and economy).

The workshop aimed to find a common (NBS-)direction, framing, and enhancement of the implementation of the vision, connecting the different subjects with each other in a way that is usable as the spatial concept for the final workshop. To achieve this, scenarios were developed, which took the food system as the foundation for exploring future directions. Three spatial propositions were developed: autarkic food provision, a regenerative and reciprocal food system, and high-tech agri-business production. These scenarios were amalgamated into one scenario that formed the basis for a common, urban [103-106] and food-forestry $[107,108]$ direction, capable of thriving alongside the restoration of the regional ecosystem.

\subsection{Workshop 3: Creating Ecologies_Implement, Solution, Manage}

Workshop three was carried out at the Hawkesbury campus, Richmond, NSW, Australia, and approximately 20 participants took part in this final workshop. The participants were largely of the same background as in the first two workshops, but with a limited number of people due to the intensity of the expected design work. While each type of participant, and their professional background, were still represented, fewer people could participate. The researchers prepared and designed the workshop, facilitated, acted as co-designers, and made sure the results were illustrated and reported.

As a first step, the design work took guidance from workshop two, with food-forestry as the conceptual framework to start the regional design. The NBS-frameworks provided the third set of inputs through the implementation, cross-cutting solutions, and management (see Figure 8) of ecosystems. This third workshop was concerned with making the visionary outcomes of workshop one and the conceptual direction derived from workshop two into 
a concrete landscape design for the Western Sydney Parklands. Practical considerations on cross-cutting issues, that work on multiple scales and are multi-actor oriented, were transformed into a concrete spatial proposal for the region, illuminating on the types of food-forests, living areas, and natural spaces were envisaged in the landscape. This third design workshop integrated the what if explorations into a spatial strategy for the long-term, creating a holistic vision of how regional urban development could become a resilient and productive urban landscape.

\section{Results}

The findings of this research are presented as outputs from the three workshops, reflecting the described methodology. However, many of these findings emerged simultaneously and should be read in parallel.

\subsection{Scanning Opportunities}

The outcomes of the first workshop were based on the identification of problems and possible visionary futures at the climate, ecological, and social systems level, aiming to recreate the regional ecosystem (type 3 NBS). The main climate change factors impacting the region were taken as the point of departure for the workshop: current maximum temperatures (up to $47^{\circ} \mathrm{C}$ ) and a maximum potential flood (MPF) [109] level of nine meters above mean water levels, must be seen as the lower limits of change. In this light, it was not enough to restore or manage existing ecosystems and, thus, envisioning a long-term future was undertaken in which the re-creation of the ecological systems was mapped out. In an iterative process, elevation, soil, vegetation, waterways, future flood-risk, and ecological remnants were mapped to understand the nuanced sensitivities of life and the reliability of available water, sunlight, shade, coolness, and other factors that determine the opportunities for the historic Cumberland Plain ecology [91] to re-appear in symbiosis with future human occupation. The landscape is there and is re-established through its creeks and side streams, the contours and potential discharge of rainwater, and the potential natural vegetation [88]. Once this landscape ecology was understood as the basis of regional planning, current steps forward could be defined: estimation of future flood risk (doubling of the current calculated MPF), the remainder of occupiable landscape, the so-called urban fields, and the infrastructural conditions for a nature-based urban development (Figure 9).

As an overarching vision, the landscape was seen as transforming by the natural terraforming forces of the free-moving creek system, shaping a resilient water system, which contains surpluses of water for later use. A transition zone between the Blue Mountains and Nepean and Hawkesbury River basin and the fine network of the South Creek system, with all its side-gullies, was established. Only then, urban infill thinking emerged.

The second major output of this first stage of the research was the mapping of the social network. The participants of the design workshop each defined their role, background, organizational embedding, and relation to every other participant (if apparent), which led to a complex inter-relational actor-network map (Figure 10). In the context of the Western Sydney Parkland development, this was seen as an important means to allow for the involvement of stakeholders and residents alike for two reasons: (1) to connect people from the region to the planning and design process, and (2) to recreate the quality of the social system. The latter was important since the south-western part of the Sydney metropolitan area is seen as lagging behind when it comes to income, education, jobs, crime, and health [42], compared with the wealthier north-west. Together with the understanding of the ecological landscape, this social landscape also played a role in gaining support for NBS, acceptance of the future vision, and permanent involvement of local people to start with during the second design workshop. 

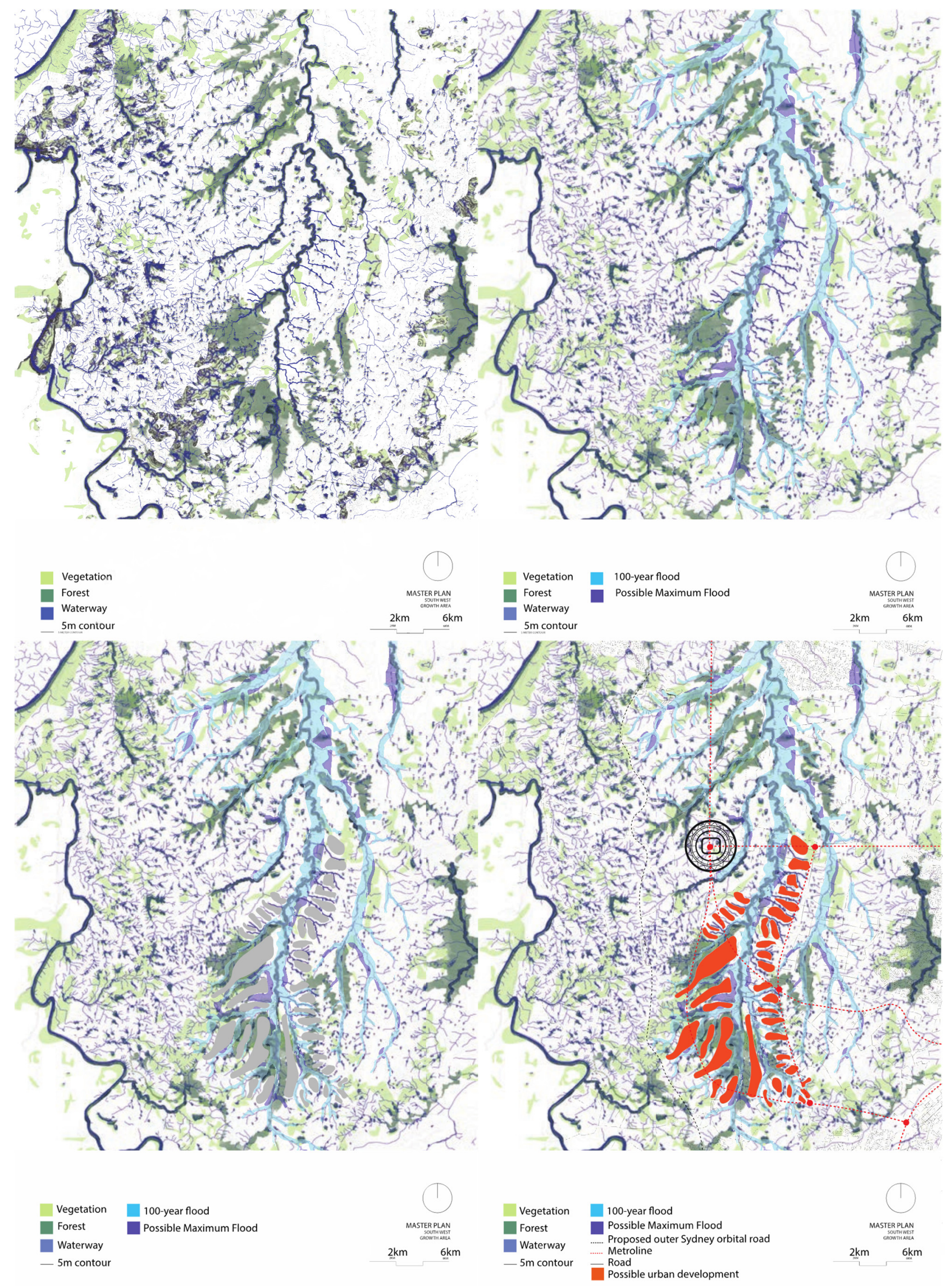

Figure 9. Landscape with elevation, water and vegetation (top left), flood-resilience (top right), urbanization potential (bottom left), and landscape urbanism and infrastructure (bottom right) (source: Mushi, Shalala, and Young [68]). 


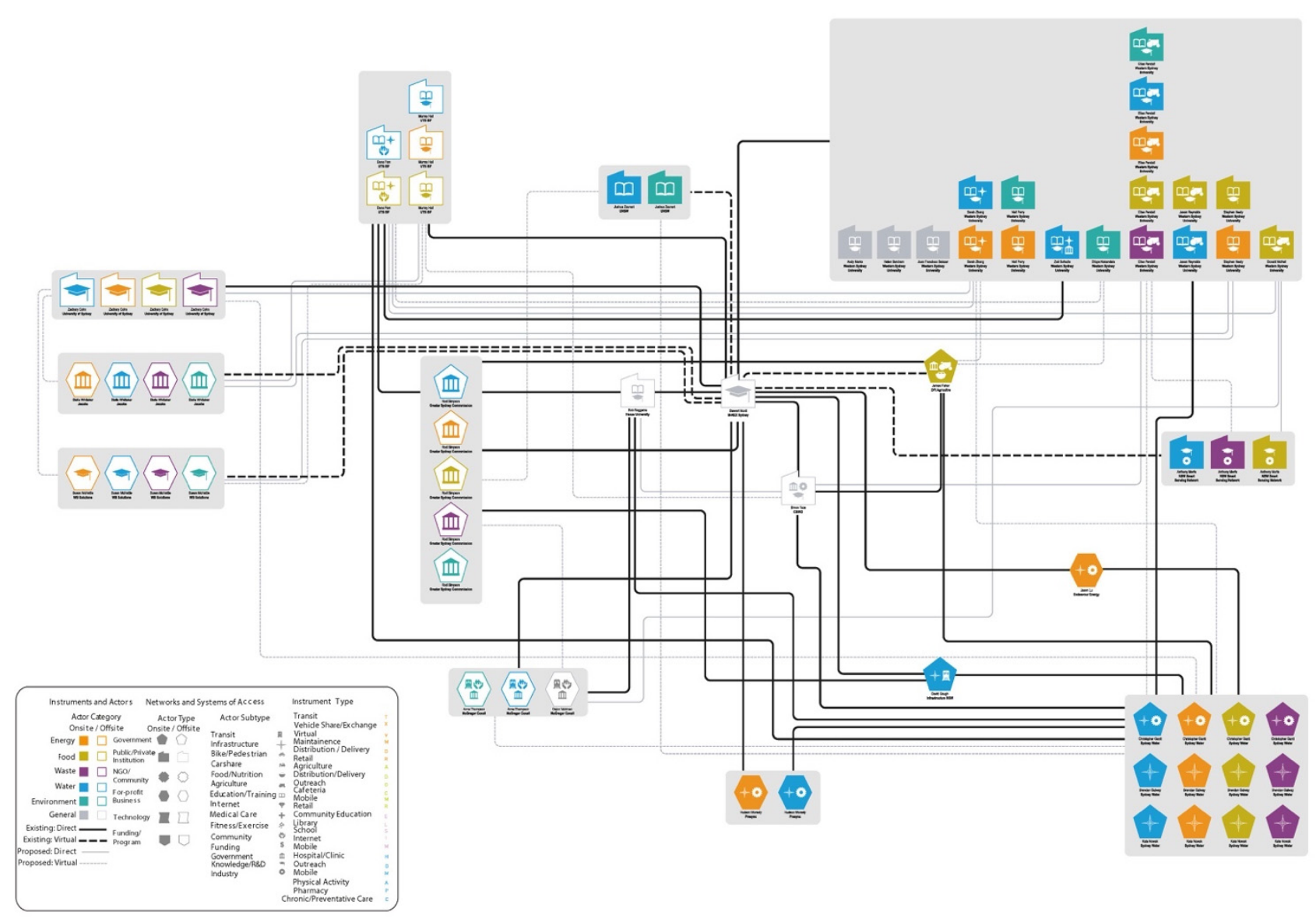

Figure 10. Actor-network mapping of the Western Sydney Parklands citizen and organizations involvement (source: Roggema and Monti; illustrated by Stewart Monti).

\subsection{Determine Directions}

The actor network that was formed during the first workshop continued working together on the evaluation of the findings during the second workshop. The long-term vision was taken as the subject to evaluate a range of relevant subjects in the Western Parklands: green, water, climate, food, participation, health, air, urban, social, and economy. To balance these subjects of ecology, sociology and economy, a uniting element was found in the choice for the type of food system as this brings in viability, connectedness, biodiversity, and the environment all at the same level. To take the full spectrum of possibilities into account, three scenarios were developed: high-tech, regenerative, and autarkic.

The first scenario (Figure 11) focused on establishing a high-tech agri-business complex. It comprised of high-intensity commercial and industrial developments surrounding the future airport. In this scenario, two unique elements were identified: aerospace and greenhouse agriculture. The South Creek flood plain was reserved and the existing Western Sydney Parklands extended further south. A key focus of this scenario was also a wastewater treatment plant integrated into the floodplain. Wastewater was captured from both the aerospace and greenhouses, along with surrounding residential areas, and fed back into the system. 


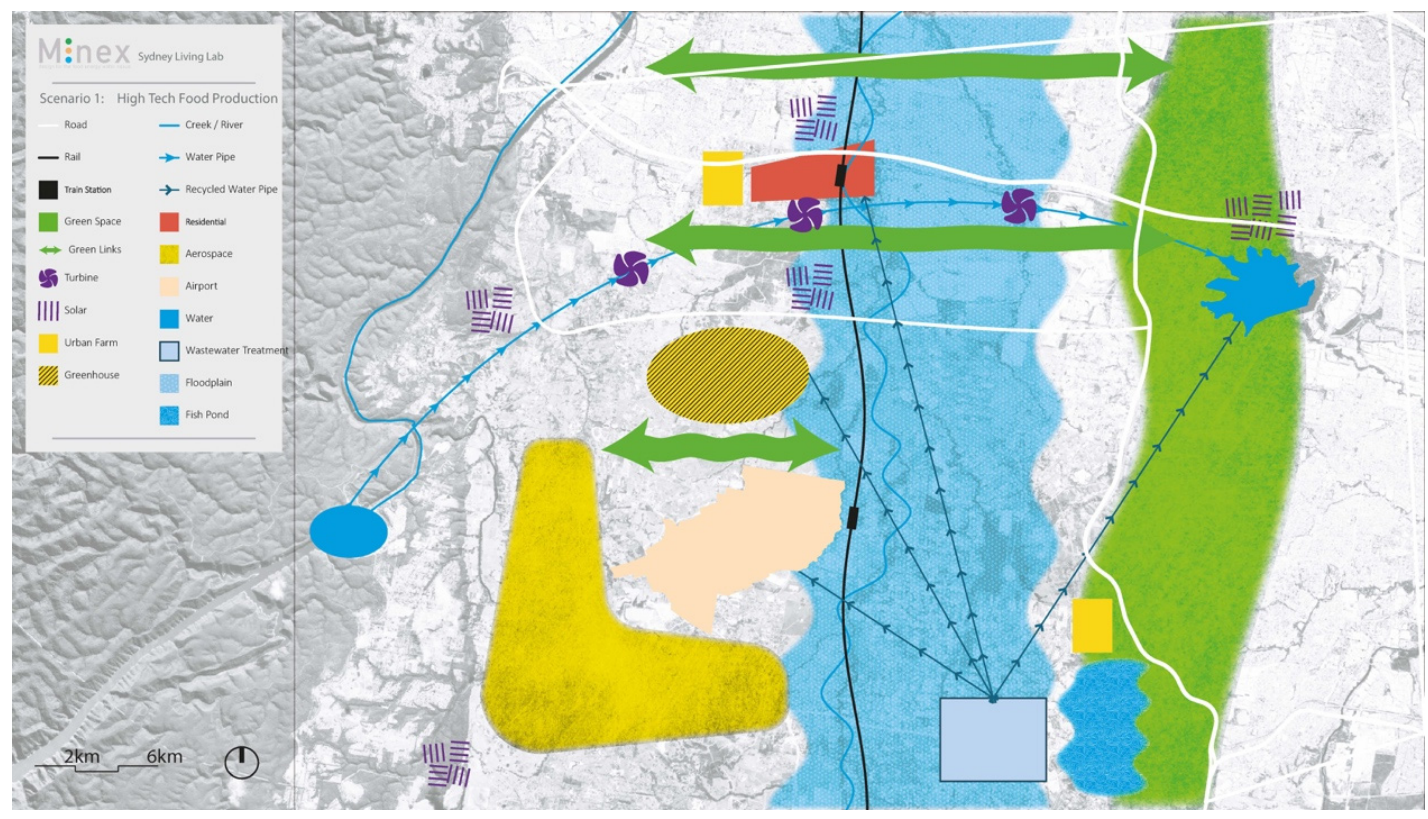

Figure 11. High-tech food system (source: Roggema and Monti; illustrated by Stewart Monti).

The second scenario (Figure 12) was based on the idea that direct linkages of producers to consumers, or smaller retailers, replace the conventional supply chain: a reciprocal foodsystem. This prosumer concept [110] assumes a significant increase in productivity at the metro-rural scale based on the advantages that come from direct purchasing. Rural villages and connections to urban agriculture in the existing city shift consumer preferences in the market. Ideally this is accompanied by an education program designed to promote eating for health to build market demand. This scenario combines agriculture and energy generation, tying it to residential areas. The daily market was seen as the node connecting these two, providing the means for producers to liaise directly with consumers. The floodplain was kept free from developments and its ecological function was only exploited for small-scale aquaculture. The airport was surrounded by a food-forest, which also provided valuable, publicly accessible green space for nearby residents.

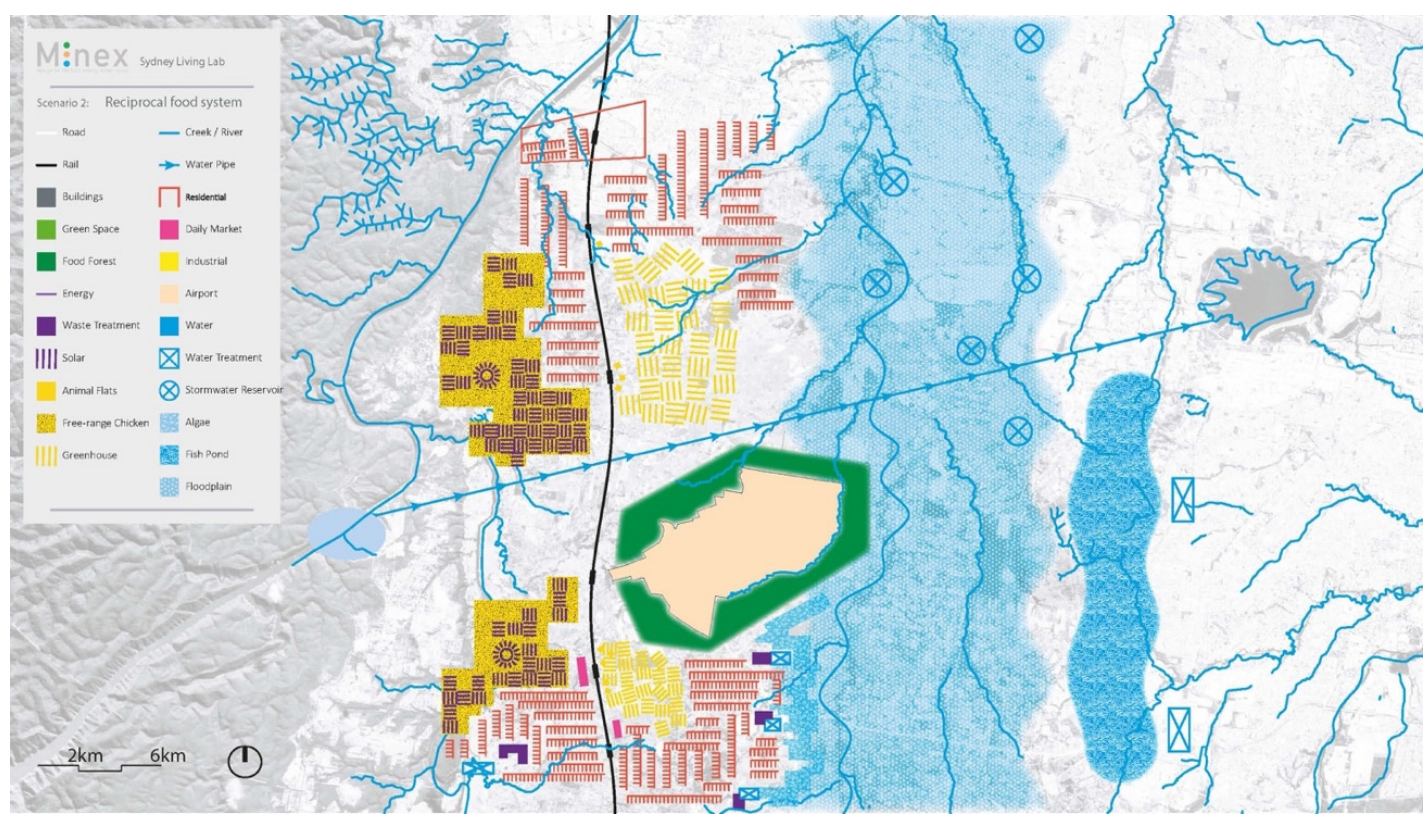

Figure 12. Regenerative food system (source: Roggema and Monti; illustrated by Stewart Monti). 
Scenario three (Figure 13) took food production as a public good, mixing agricultural typologies carefully attuned to the characteristics of particular locations. Autarkic and regenerative food production improves soil and water qualities, increases biodiversity and resilience, recycles nutrients, and supports bio-sequestration. This implies new forms of co-governance, providing incentives for local food production. A pair of new parklands were introduced, which also run north to south. Agricultural production would take place within these new parklands. On the fringes of these areas, farms were coupled with associated services, residential, energy production and water treatment, to create self-sufficient communities linked by active transport routings.

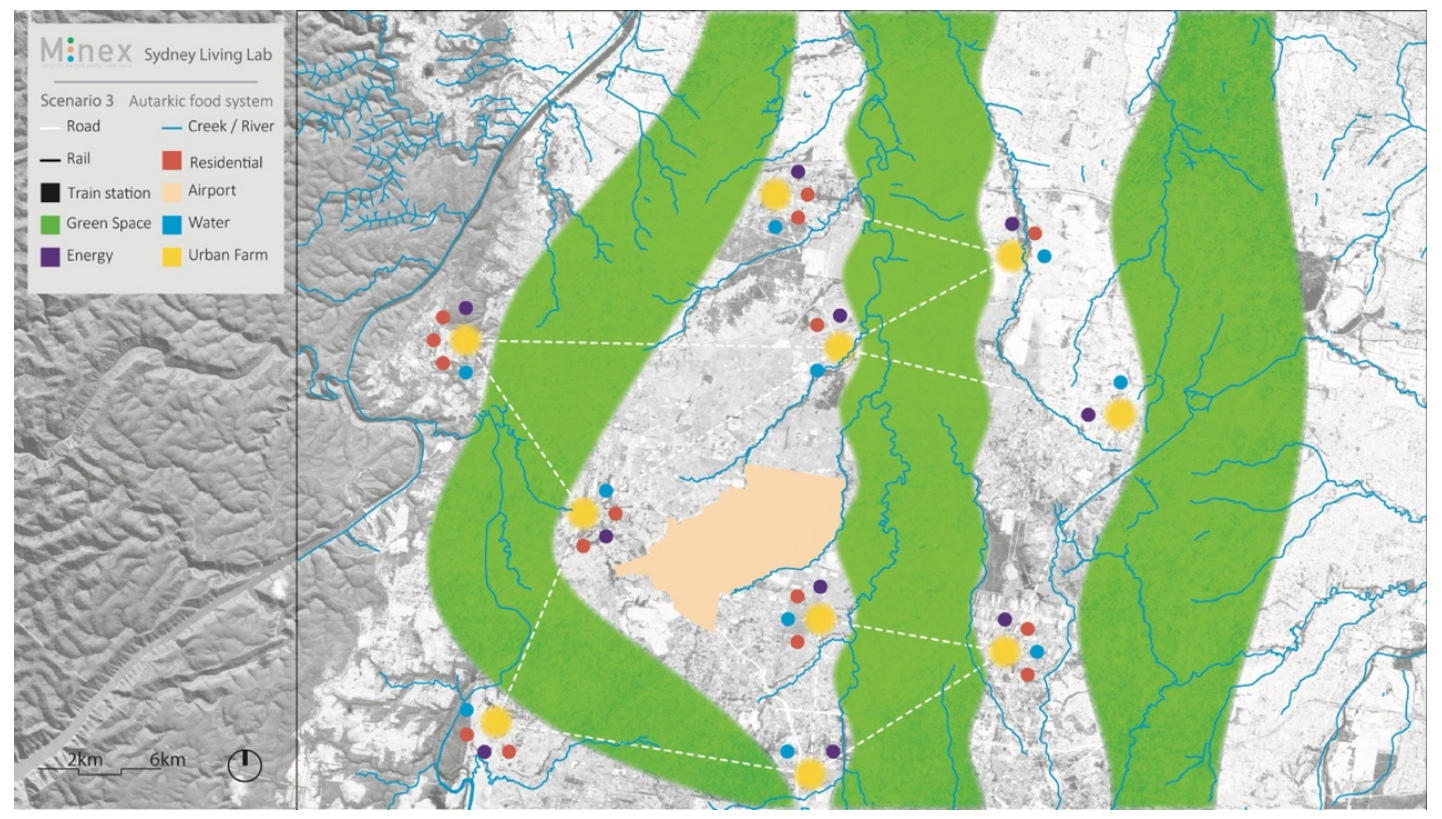

Figure 13. Autarkic food system (source: Roggema and Monti; illustrated by Stewart Monti).

The amalgamation scenario (Figure 14) subsumes aspects of each individual scenario in one tripartite vision. Resilience is the most influential conceptual practice underlining future city-making. It closes food, energy, and water loops, creating a purifying city which commonly manages its resources [111]. It incorporates Aboriginal custodians' knowledge and generates the realization of the so-called OCHRE strategy, which takes Aboriginal values as the foundation for planning and development [112]. Moreover, it introduces localized, regenerative agriculture for remediation which can "start replenishing and treatment at the source then move downstream". It proposes an active community engagement and co-design process shaped as a living lab, applying quadruple helix cogovernance. In the amalgamation scenario, there is an important role for the resilience of the South Creek, which was not only recreated as an ecological floodplain area, but was also restored to its historic eco-qualities.

Derived from the amalgamated food-system, a spatial strategy was conceived, which could restore the natural system while meeting the needs of current demands, such as future climate, flood, heat, food, housing, biodiversity, recreation, social interaction, and economic viability. It embraced the vision of a landscape that satisfied the need to create a cooling environment, in which vegetation, water, and shade rhizomatically ramify themselves in smaller branches. The creative working process resulted in the conclusion that a food-forest strategy could bring multiple benefits: operating as a sponge, providing building materials for urban development, increasing biodiversity, and supplying indigenous and local food to the residents of the new city. Planting eight million trees, one for every resident living in the Sydney metropolitan area in 2045, would allow them to start growing, capturing carbon and nitrogen, creating timber for construction purposes, and provide a cooling canopy for later urban infill. 


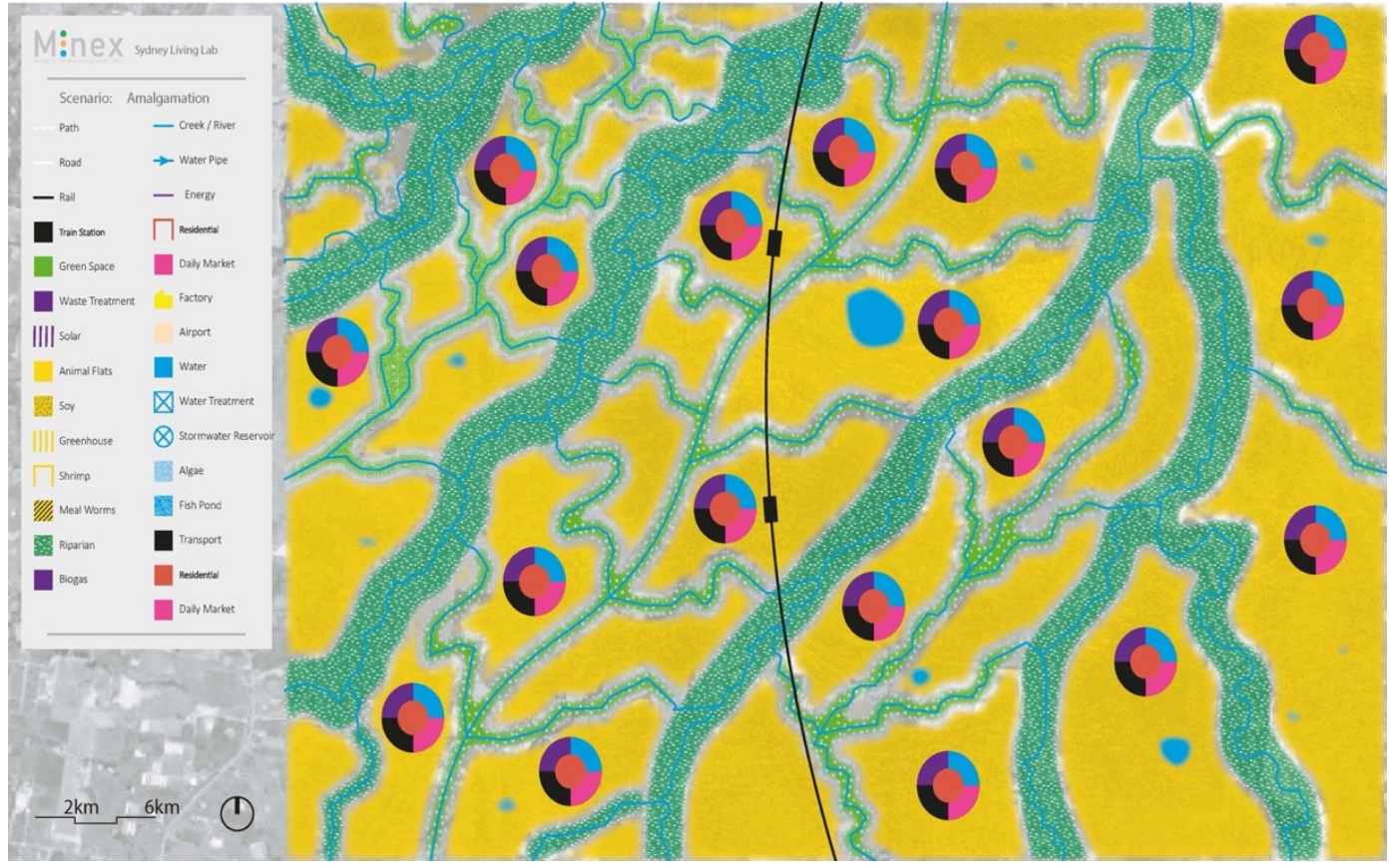

Figure 14. Amalgamated scenario (source: Roggema and Monti: illustrated by Stewart Monti).

The six proposed forest typologies (Figure 15) relate to indigenous forest communities of the Sydney metropolitan area [91] and depend on local factors, such as the soil, humidity, and climate, and require mixed planting (indigenous fruit, special timber, and nuts) or a link to permaculture when dealing with food-forests.
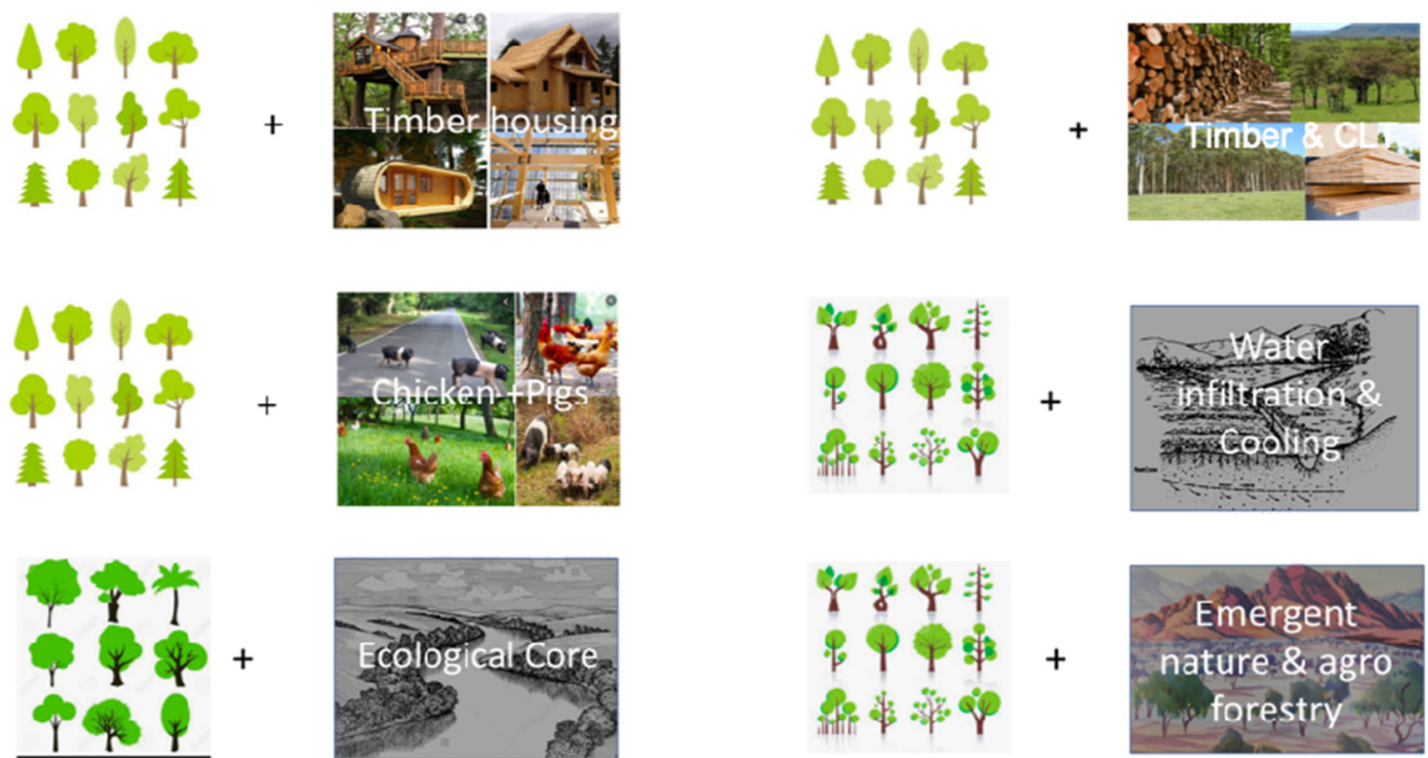

Figure 15. Food-forest typologies (by the authors).

The six typologies are described as follows:

1. A forest in which water can be stored so the environment can be cooled, flattening the potential flood risk. Riparian forest communities are used to flooding and, thus, form a buffer between areas where people live and the (potential) floodplains of the creeks. Apart from the water in the creeks and the evapotranspiration, the shade of the extended tree canopy network results in a much cooler environment. At the same time, these forests form ecological corridors in the region, linking similar habitats. 
For these areas near the rivers, the use of alluvial woodland, with common species such as Eucalyptus amplifolia, E. tereticornis, and Angophora floribunda, and riparian forests, with common species Eucalyptus botryoides, E. elata, Angophora subvelutina and A. floribunda, were suggested [91];

2. A forest operating as an emerging ecological reserve. Due to deforestation and the pressure of different forms of land use, such as housing development and agriculture, some habitats and linked species can only be found in small pockets of land. Some of these species are rare and endemic. These are relics from historic ecosystems which are slowly disappearing or becoming extinct;

3. A forest used as timber production for building materials. Some areas in the timber forests are meant to be cut (checkerboard pattern) and used for buildings being built at the open patches in the direct vicinity;

4. A forest used as the producer of cross laminated timber (CLT). As some of the timber forests are meant to stay, with ongoing thinning as harvest products for timber and CLT, the set up might be different than traditionally managed timber forests.

For typologies two, three, and four, the Sydney Turpentine-Ironbark Forest, typical of the inner west region, was proposed. This forest type is indigenous to the Sydney metropolitan area and is classified as endangered under the Threatened Species Conservation Act 1995 [113]. This forest community can be very well used in typology two and its common species may serve as a base for typologies three and four. The forest type is dominated by Syncarpia glomulifera with Eucalyptus paniculata and E. eugeniodes occurring less frequently [92]. The Syncarpia glomulifera, or turpentine tree, is highly durable, as its timber is used in heavy-traffic flooring and for poles and wharves. It resists marine invertebrates and termites and is one of the most difficult timbers to ignite [114]. It is described as a hardy and adaptable tree, as turpentine tolerates heavy soils and frosts and is suitable for large gardens and parks, where it provides good shade with its dense canopy $[115,116]$.

5. A forest used as a food-growing area (agroforestry). In many of these systems, trees and woody perennials were combined with growing fruits, nuts, and vegetables (annuals). The local opportunity here is to grow native products which are often unknown to consumers. This means making use of indigenous knowledge of plants and food production. Again, this strengthens biodiversity and resilience, and makes people care for their environment;

6. A forest used as a home to free-range pig and chicken farming. It is well known that boars were raised in forests on the island of Corsica in combination with rich productive forests. The boars were fed on chestnuts, corns, and fruits. However, the animals should be part of a well-balanced flow of nutrients and be a sustainable part of the agroforestry system [117].

For typologies five and six, prevailing local forest communities are suggested in combination with permaculture techniques. As this would influence the humidity of the soil over time, more moist-appreciating species could gradually be added to the range of species. With bushfire controlling strategies and the use of different forest typologies, an extended, biodiverse, and multifunctional forest could be created based on traditional knowledge [118]. Although site-specific studies need to be done, the overall effect of growing extended forests in Western Sydney would be that rainfall, especially in dry summers, would increase. Wright et al. found that transpiration helped to drive the seasonal cycle of rainfall in the southern Amazon [119]. These typologies can be used as the design principles in an intelligent combination to direct climate adaptive forms of urbanization.

This forest strategy gave direction to the regional spatial design explorations that were the subject of the third and final design workshop. 


\subsection{Create Ecologies}

The third stage of the research, e.g. the third design workshop, focused on designing the implementation of solutions and looking at the way ecosystems can be managed in an urban context. This built upon the directions from research stages one and two, embracing the long-term vision, putting the landscape at the heart of future regional planning, and directing the regional plan from a food-forest perspective using the six indigenous forest typologies. In this way, NBS were connected to the social and economic systems through enriching urban livability and human health, demands for recreation, food production, circular resource management, and community engagement and co-creation of the future.

Here the results are presented in a series of six mapping stages as an emergence of ecologies (Figure 16a-e).

First, the current water network is captured (Figure 16a). The flow of the main water courses is based on the local topography, determining the ecological gradients and pathways of discharging waterflows through the landscape. The expected flood risks appear in the zones next to the main streams.

Second, alongside the streams, a riparian zone was planned (Figure 16b) in which wet forests would create the ideal conditions for sensitive ecologies, increasing biodiversity and where surpluses of floodwater could be captured, preventing flooding in other parts of the urban landscape.

The third stage entailed the introduction of an ecological grid (Figure 16c) forming the frame for structural ecological connections, linking wet and dry, and nutrient-rich and -poor parts of the landscape. This framework allows for an increased ecological connectivity and exchange, enhancing eco-capacity.

Stage four introduces plantations of timber forests in the inner parts of the ecoframework (Figure 16d) to produce building materials for homes. This timber is grown in areas of $1 \mathrm{~km}^{2}$, within which housing compounds in high densities were foreseen, with each compound home to about 20,000 people. In the entire Western Sydney Parkland, 50 of these timber cities, in total, could be planned on the higher parts of the region, totaling up to the one million people that are projected to live in this area.

The remaining area within the inner framework (Figure 16e) was designed as a mix of productive agroforestry for fruits and vegetables and some intensive forms of food production, such as aero- and hydroponics.

Finally, under the future flightpath, the food-forest would host free-range chicken and pig farming (Figure 16f) where the animals can, within limits, forage freely under and in between the trees, providing high-quality products from local land. The remaining land was made redundant as a future spatial resource, which could be made productive if circumstances, demands, or developments change. It could be used to grow food or be developed on an ecological basis.

Together, these forest typologies simultaneously build up the landscape and the city. The quality of the urban environment co-evolves with the enrichment and increase of natural values. It contributes to the resilience for sudden climatic changes and impacts that cannot clearly be foreseen. Finally, it provides the urban population with a natural recreation space and a healthy environment to live in or nearby. 


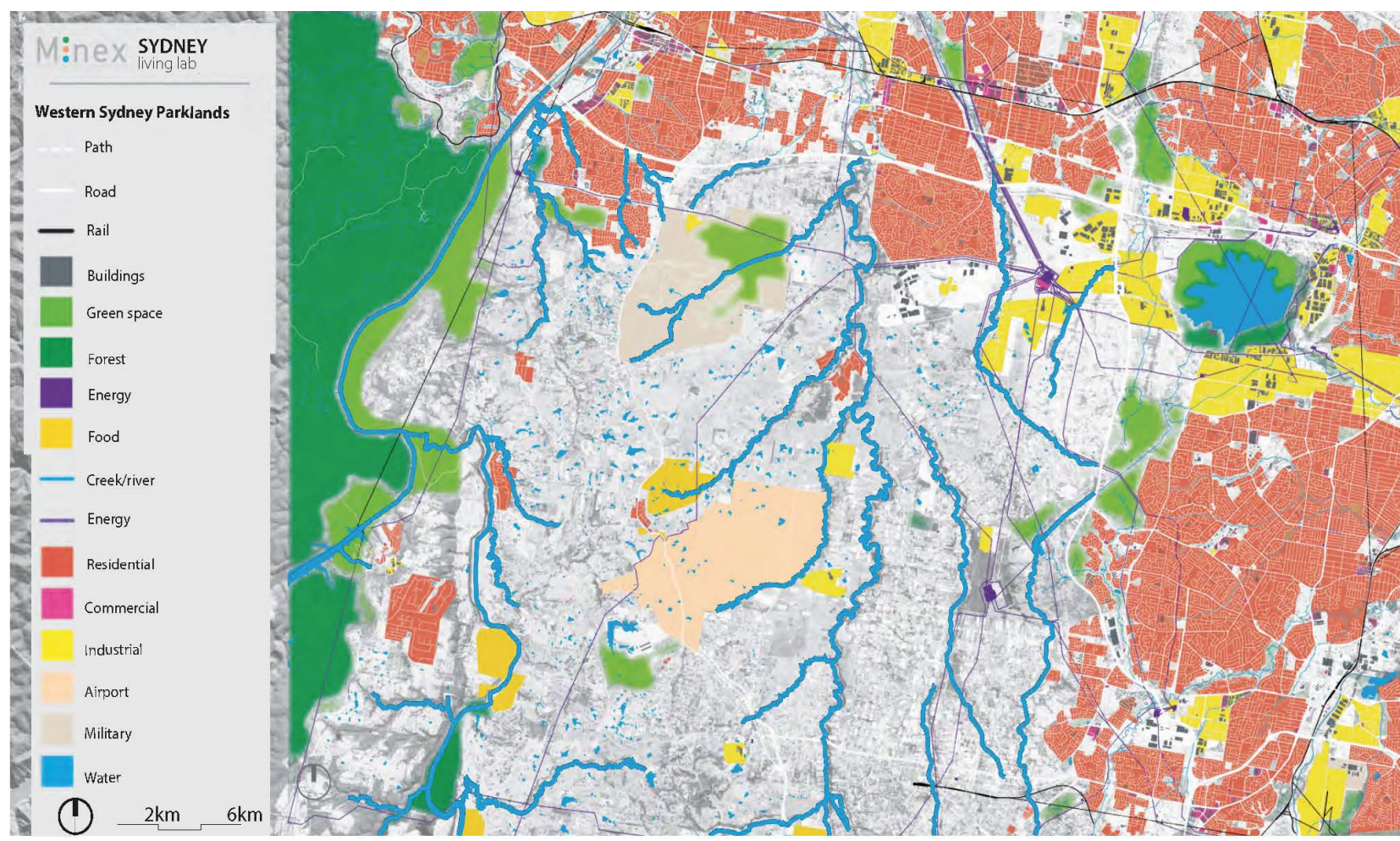

(a)

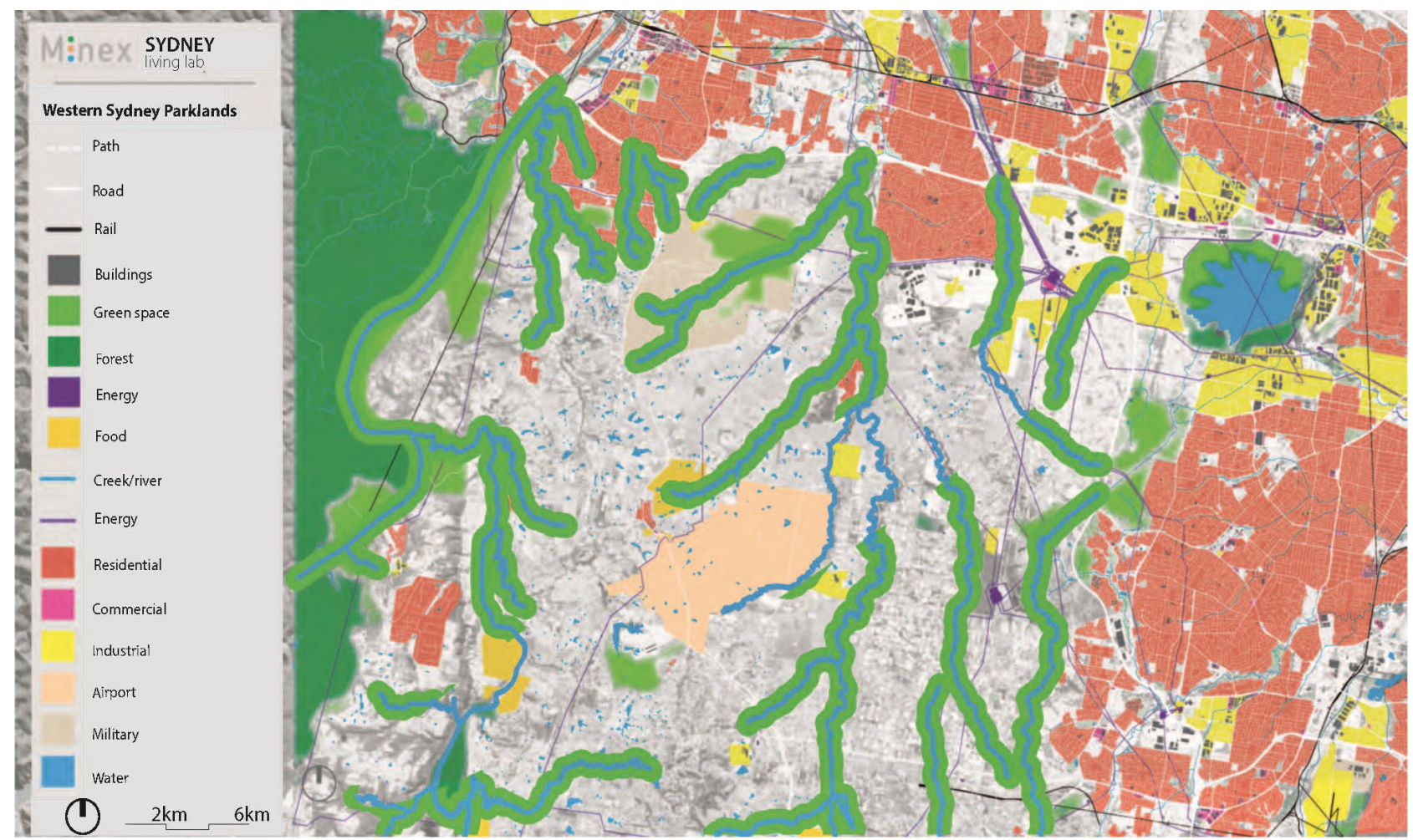

(b)

Figure 16. Cont. 


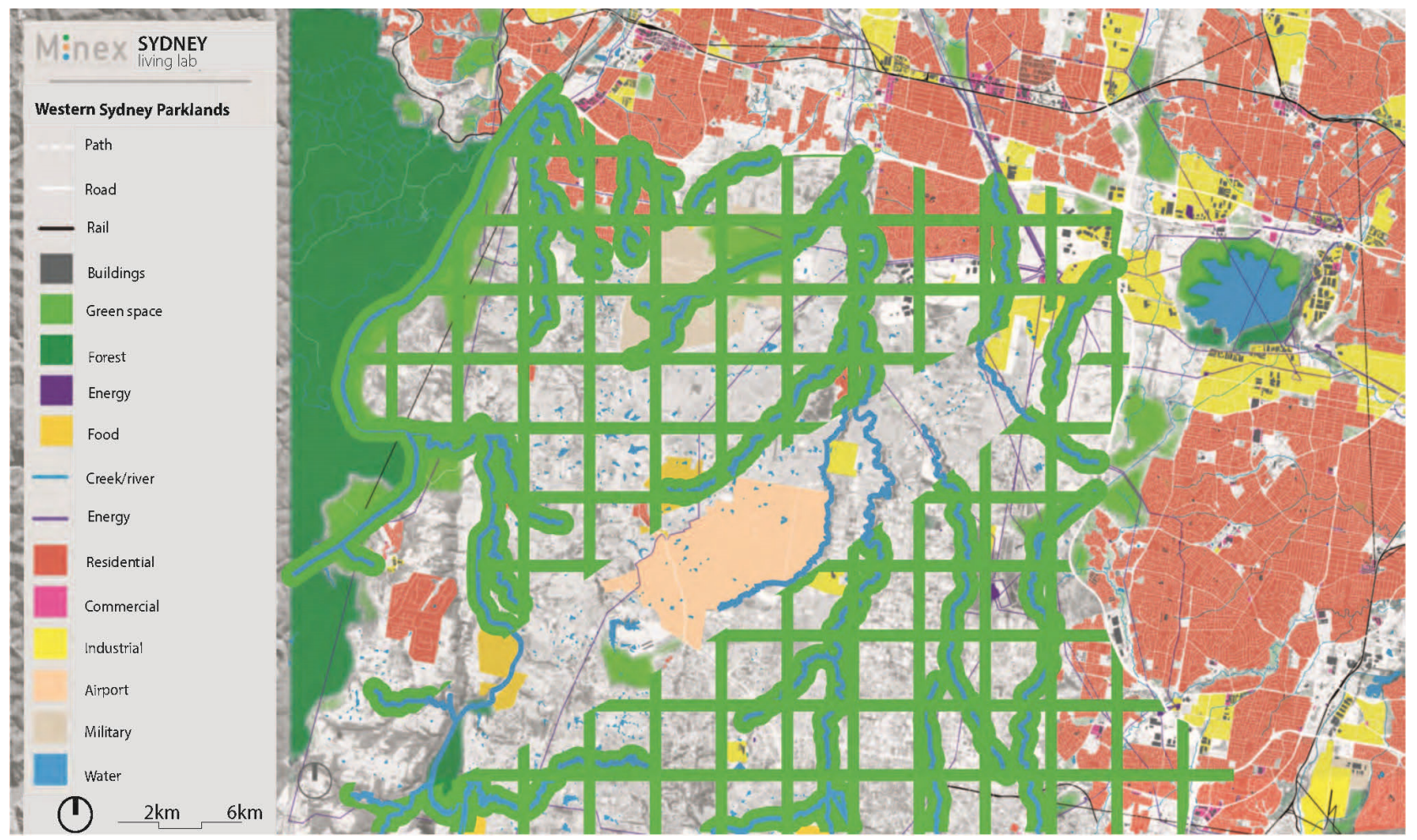

(c)

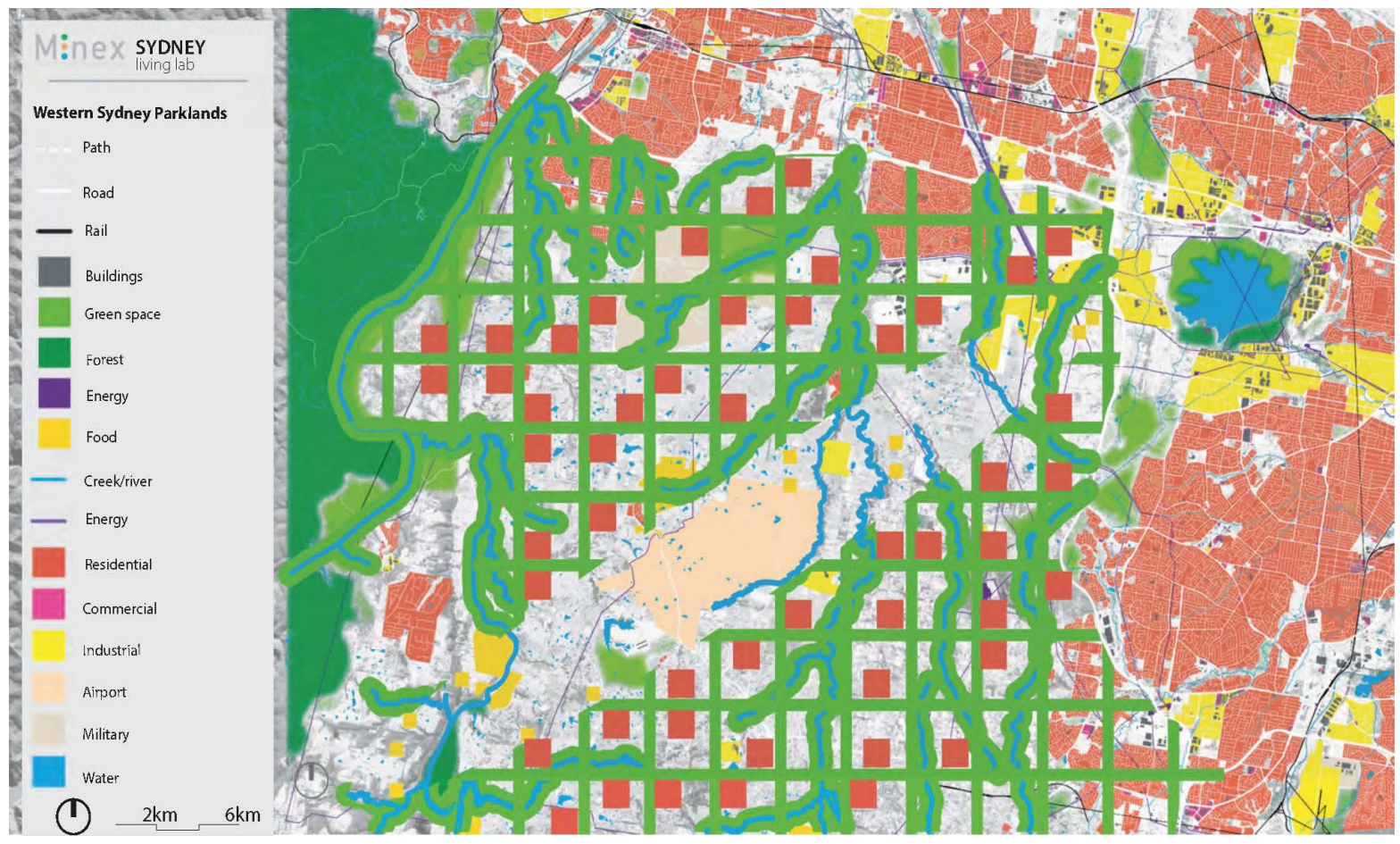

(d)

Figure 16. Cont. 


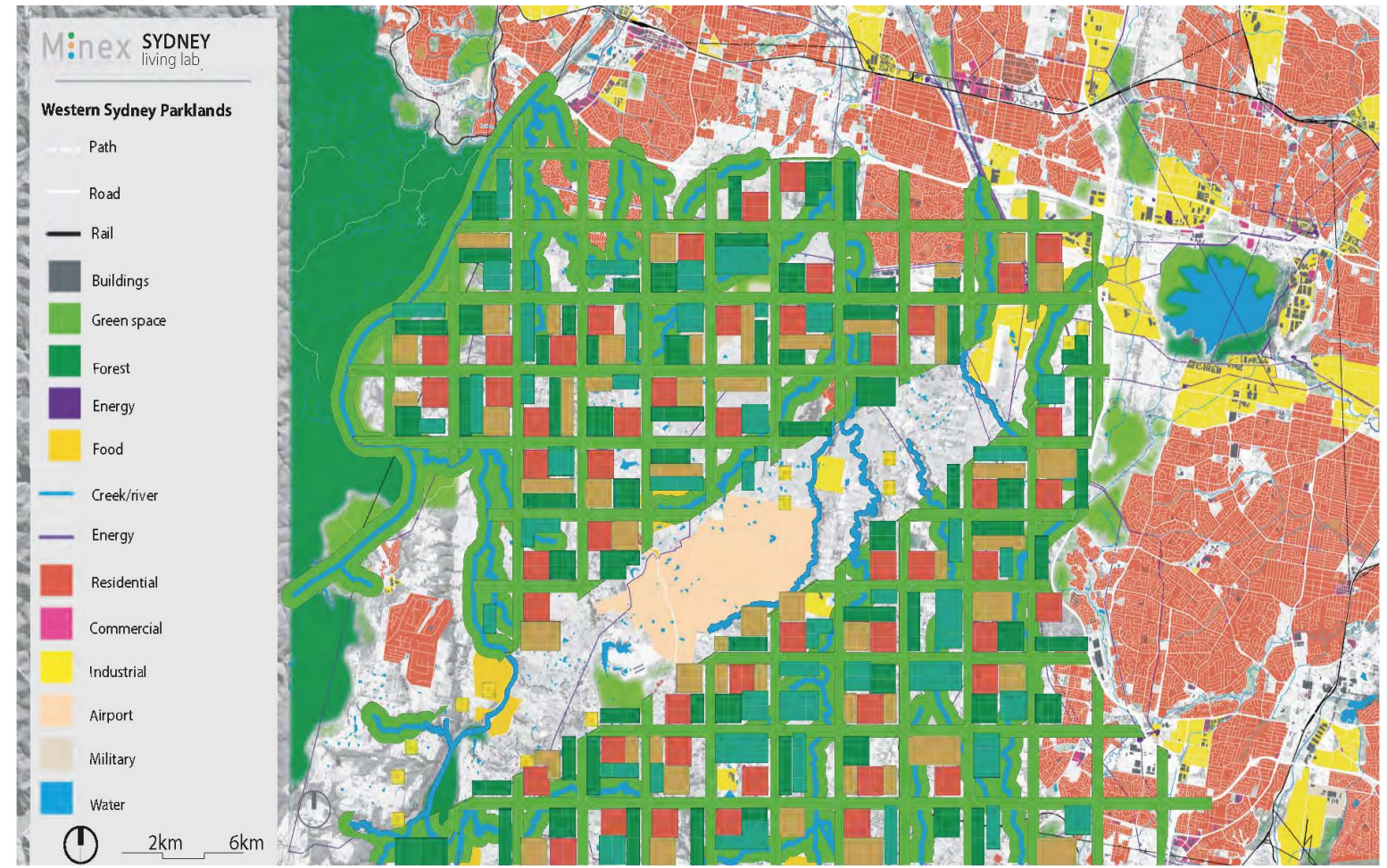

(e)

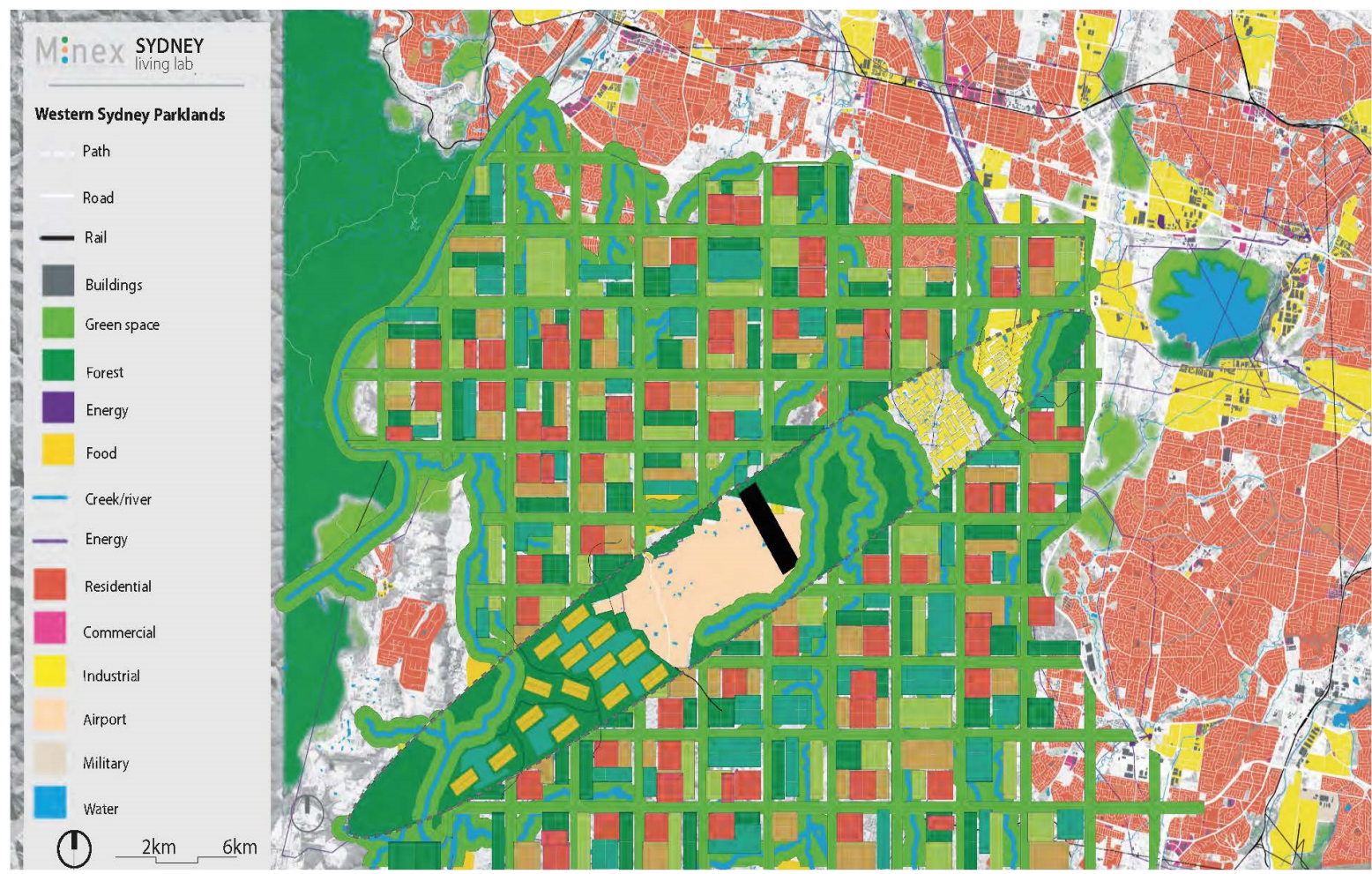

(f)

Figure 16. (a) Elevation and water courses (source: by the authors; illustrated by Stewart Monti), (b) Riparian ecology zoning of the water system (source: by the authors; illustrated by Stewart Monti), (c) Ecological grid connecting water and ecological landscapes (source: by the authors; illustrated by Stewart Monti), (d) Housing compounds embedded in the ecological grid (source: by the authors; illustrated by Stewart Monti), (e) Agroforestry of fruit, vegetable, and small cattle farming within the compounds of the eco-grid (source: by the authors; illustrated by Stewart Monti), (f) Free range cattle under the flightpath (source: by the authors; illustrated by Stewart Monti). 


\section{Discussion}

\section{NBS: hype or novel theory?}

NBS is a relatively recent concept, and a range of literature has emerged aiming to theorize on it. A broad spectrum of topics is related to NBS: social, climate, economy, health, green, water, and many more. It is applied to different spatial scales and used in rural, natural landscapes as well as in urban contexts. There is a common feeling about NBS that it is appealing and a potential denominator for creating more resiliency. There are assessment frameworks developed and the concept is used in (urban) planning and concrete projects, some of which are suddenly dubbed nature-based. Therefore, the question that can be asked is whether NBS is hype or a novel theory? For NBS to become an autonomous theory, there should be a unique aspect to it, not just a next (or alternate) label for creating more ecological cities or landscapes. If NBS is only reframing the concept of ecosystem services or thinking in green grids or urban green-blue infrastructure, the danger of copying old concepts, including the reasons for failure, is apparent. Instead, NBS should offer new theoretical insights, for instance regarding the role nature-based takes on in the planning process. This requires further debate about the exact meaning of nature-based in a spatial planning environment and in urban development.

\section{Nature as basis in a dynamic context?}

In addition to the above, the implications of taking nature as the basis for solving current and future problems concerning the resilience of cities and landscapes, it can be stated that nature (ecosystems, water systems, the landscape, biodiversity, and all their interrelations) should be the driving force for every development. This goes beyond conserving species or (eco-)systems and aims to understand the functioning of the natural system, improving this through sensitive urban and rural planning and design. The question that deserves more attention is how this understanding of nature can be made applicable in a dynamic planning context.

\section{NBS: detailed assessment or guide for design?}

Some argue that by measuring and assessing elements of NBS, these will lead to an easier realization of these solutions. Therefore, several frameworks were proposed, some of which were used in this article. However, the level of detail and the abundance of subjects incorporated into these frameworks increase their complexity and decrease the ease of applying them in a practical planning process. There is a tension between the desire to assess the effect of NBS in detail and the use of more abstract guidance, derived from the frameworks, in conceiving designs that establish and realize NBS in concrete situations. In this article, three frameworks were used to define the direction of thought and, thus, make the NBS frameworks applicable in the design process at three abstraction levels. The discussion could be taken further by exploring an optimal balance between a detailed or an all-encompassing assessment and an abstraction of this and the relative freedom of thought to mold NBS-designs.

This, then, would make it possible to use the NBS-theoretical frameworks in practical design processes. To be useful, the frameworks need to give enough freedom to allow for the searching of novel applications and solutions, while at the same time directing the designers in the process towards basing their solutions on the desired natural qualities, an increase in biodiversity or extensions of ecological areas and corridors.

The interpretation of NBS in a design process is a matter of perspective. Planning NBS could take, at least, three dimensions: (1) when cities and landscapes are designed, integrate more NBS as part of the plan, (2) design cities and landscapes based on nature, and (3) design the desired regional and local ecosystem as one large nature-based solution. These preliminary directions require further elaboration.

\section{NBS: beyond the urban-rural?}

The urban-rural dichotomy is dominating the way our cities and landscapes are planned. This paradigm of separating the urban from the rural leads to distinct approaches 
for rural NBS and NBS in cities. The essence of ecological systems, however, is interconnectivity between the urban and the rural. This implies that NBS should be developed for the entire continuum of the city-urban and fringe-rural, demanding one coherent approach.

\section{NBS as the subject in participatory planning}

Finally, the success of NBS could be related to the design process. A participatory planning approach, suggested in this article, emphasizes the role of stakeholders and citizens in the conception of design solutions. This brings expert views and laymen visions together and allows for non-design experts to be directly involved, co-design, and understand proposed NBS. This results in more support for the future vision and less obstruction afterwards. This, as opposed to top-down governmental planning processes or even designer-led visionary approaches, which might be technically the best solution, yet are not always the perceived best solution.

\section{Conclusions}

\section{Designing resilient landscapes using abstractions of NBS-frameworks}

Current urban development places the urban in the development first, leading to suboptimal or poor outcomes for biodiversity and resilience. NBS is seen as a potential way to create better solutions for both humans and non-humans. In this article, NBS frameworks were used in the design process, enabling the exploration of planning that considers these aspects more thoroughly. The use of three NBS frameworks drove the design process. To achieve a fluid design process, the detailed and all-encompassing nature of the frameworks were abstracted at three levels, forming the input for three consecutive creative design workshops. At the highest level, the long-term visioning took place in which the re-creation of socio-ecological systems could be envisioned in the form of a regional landscape. This vision was then evaluated at the second level of abstraction, subject-by-subject, and led to concrete design directives, in the form of a commonly conceived food-forest strategy, to be implemented at the lowest level of abstraction: cross-cutting solutions, integrating a spectrum of concrete design aspects related to NBS at the regional planning scale.

\section{NBS: connecting the dots through a spatial food-forest strategy}

A food-forest strategy, as proposed in this article, offers good opportunities to connect a range of ambitions to enhance ecology, water conservation, timber production, the growth of food, livability, and health. The multiple benefits of forest typologies can structure the urban configuration, is well placed to anticipate future change, increase ecological values, and provide the building materials and space for food production in conjunction with urban spaces. A multifaceted and integrated approach concerning planning, participation, and ecological resilience is highly relevant. It makes sense to use NBS to direct the urban design and planning practice to, not only, increase the size of nature reserves, or improve nature's quality, but to develop a systemic urban future, which is more resilient and healthier to both its natural inhabitants as well as its human ones.

\section{NBS: putting the ecological landscape first}

The shifting mindset is to put the ecological landscape first in the planning process, followed by enriching and extending the ecological resilience and qualities, and, ultimately, embedding urban uses and provisions into the plan. By analyzing the current vulnerabilities and systemic characteristics of the ecological and water systems in the landscape, NBS informs and guides urban planning. The plan for the Western Sydney Parklands offers a systemic change, both in the way of working (putting landscape first in the design and planning process), as well in the time horizons considered (using the growth of plants and trees as the timeframe of development). System innovations like these imply systemic changes and enable ecological, social, and technological innovations, as well as the interaction between them. An (urban) design approach in which the landscape is taken as the point of departure brings nature-based planning and design practice to the fore, supporting the implementation of resilient and ecological solutions. When landscape is put first, the 
starting point of the planning and development of cities begins on a different foot and uses NBS as strategic spatial guiding principles.

Author Contributions: Conceptualization and methodology: R.R.; investigation, R.R., G.K., N.T.; writing—original draft preparation, R.R.; writing—review and editing, R.R., G.K., N.T.; visualization, R.R.; supervision, R.R.; project administration, R.R. All authors have read and agreed to the published version of the manuscript.

Funding: This research received no external funding.

Informed Consent Statement: Not applicable.

Acknowledgments: The authors wish to acknowledge the support of Western Sydney University for the facilitation and support throughout the workshops that founded this study. Moreover, we want to express our gratitude to Stewart Monti for visualizing the results of the workshops, and acknowledge the support in preparing the manuscript of Anouk Roggema.

Conflicts of Interest: The authors declare no conflict of interest.

\section{References}

1. WWF. Living Planet Report 2020—Bending the Curve of Biodiversity Loss; Almond, R.E.A., Grooten, M., Petersen, T., Eds.; WWF: Gland, Switzerland, 2020.

2. Brink, M. Country Report for The State of the World's Biodiversity for Food and Agriculture-The Netherlands; Centre for Genetic Resources, The Netherlands (CGN), Wageningen University and Research Centre (WUR): Wageningen, The Netherlands, 2015; p. 92.

3. PBL. Halting Biodiversity Loss in the Netherlands: Evaluation of Progress; Planbureau voor de Leefomgeving Den Haag: Den Haag, The Netherlands, 2008.

4. PBL. Balans van de Leefomgeving 2014. De Toekomst Is Nú; Planbureau voor de Leefomgeving Den Haag: Den Haag, The Netherlands, 2014. Available online: https:/ / themasites.pbl.nl/balansvandeleefomgeving/wp-content/uploads/PBL_2014_Balans-van-deLeefomgeving-2014_1308.pdf (accessed on 31 May 2021).

5. Crutzen, P.J. Geology of mankind. Nature 2002, 415, 23. [CrossRef]

6. Seto, K.C.; Fragkias, B.G.; Reilly, M.K. A meta-analysis of global urban land expansion. PLoS ONE 2011, 6, e23777. [CrossRef]

7. Schubert, D. Cities and plans-The past defines the future. Plan. Perspect. 2019, 34, 3-23. [CrossRef]

8. Molotch, H.; Freudenburg, W.; Paulsen, K. History repeats itself, but how? City character, urban tradition, and the accomplishment of place. Am. Sociol. Rev. 2000, 65, 791-823. [CrossRef]

9. Sijmons, D. Het Casco-Concept, een Benaderingswijze voor de Landschapsplanning; Ministerie van LNV, Directive NBLF: Utrecht, The Netherlands, 1992.

10. Tjallingii, S.P. Ecopolis: Strategies for Ecologically Sound Urban Development; Backhuys Publishers: Leiden, The Netherlands, 1995.

11. Tjallingii, S. Planning with water and traffic networks. Carrying structures of the urban landscape. Res. Urban Ser. 2015, 3, 57-80. [CrossRef]

12. Roggema, R.; van den Dobbelsteen, A.; Biggs, C.; Timmermans, W. Planning for Climate Change or: How Wicked Problems Shape the New Paradigm of Swarm Planning. In Proceedings of the 3rd World Planning Schools Congress, Perth, Australia, 4-8 July 2011.

13. Niemela, J. Ecology and urban planning. Biodivers. Conserv. 1999, 8, 119-131. [CrossRef]

14. Goddard, M.A.; Dougill, A.J.; Benton, T.G. Scaling up from gardens: Biodiversity conservation in urban environments. Trends Ecol. Evol. 2010, 25, 90-98. [CrossRef]

15. Haase, D.; Larondelle, N.; Andersson, E.; Artmann, M.; Borgström, S.; Breuste, J.; Gomez-Baggethun, E.; Gren, Å.; Hamstead, Z.; Hansen, R.; et al. A quantitative review of urban ecosystem service assessments: Concepts, models, and implementation. AMBIO 2014, 43, 413-433. [CrossRef]

16. Kabisch, N.; Qureshi, S.; Haase, D. Human environment interactions in urban green spaces-A systematic review of contemporary issues and prospects for future research. Environ. Impact Assess. Rev. 2015, 50, 25-34. [CrossRef]

17. European Commission. Towards an EU Research and Innovation Policy Agenda for Nature-Based Solutions \& Re-Naturing Cities. Final Report of the Horizon 2020 Expert Group on 'Nature-Based Solutions and Re-Naturing Cities'; Publications Office of the European Union: Luxembourg, 2015.

18. Mccormick, K. (Ed.) Cities, Nature and Innovation: New Directions; Lund University: Lund, Sweden, 2020.

19. The EU and Nature-Based Solutions. Available online: https:/ / ec.europa.eu/research/environment/index.cfm?.pg =nbs (accessed on 12 November 2020).

20. Cohen-Shacham, E.; Janzen, C.; Maginnis, S.; Waters, G. Nature-Based Solutions to Address Global Societal Challenges; IUCN: Gland, Switzerland, 2016. 
21. Emilsson, T.; Sang, A.O. Impacts of Climate Change on Urban Areas and Nature-Based Solutions for Adaptation. In Nature-Based Solutions to Climate Change Adaptation in Urban Areas—Linkages between Science, Policy and Practice; Kabisch, N., Korn, H., Stadler, J., Bonn, A., Eds.; Springer: Cham, Switzerland, 2017; pp. 15-28.

22. Pauleit, S.; Zölch, T.; Hansen, R.; Randrup, T.B.; Konijnendijk van den Bosch, C. Nature-Based Solutions and Climate ChangeFour Shades of Green. In Nature-Based Solutions to Climate Change Adaptation in Urban Areas-Linkages Between Science, Policy and Practice; Kabisch, N., Korn, H., Stadler, J., Bonn, A., Eds.; Springer: Cham, Switzerland, 2017; pp. 29-50.

23. Depietri, Y.; McPhearson, T. Integrating the Grey, Green, and Blue in Cities: Nature-Based Solutions for Climate Change Adaptation and Risk Reduction. In Nature-Based Solutions to Climate Change Adaptation in Urban Areas-Linkages Between Science, Policy and Practice; Kabisch, N., Korn, H., Stadler, J., Bonn, A., Eds.; Springer: Cham, Switzerland, 2017; pp. 91-110.

24. Haase, D. Urban Wetlands and Riparian Forests as a Nature-Based Solution for Climate Change Adaptation in Cities and Their Surroundings. In Nature-Based Solutions to Climate Change Adaptation in Urban Areas_Linkages between Science, Policy and Practice; Kabisch, N., Korn, H., Stadler, J., Bonn, A., Eds.; Springer: Cham, Switzerland, 2017; pp. 111-122.

25. Enzi, V.; Cameron, B.; Dezsényi, P.; Gedge, D.; Mann, G.; Pitha, U. Nature-Based Solutions and Buildings-The Power of Surfaces to Help Cities Adapt to Climate Change and to Deliver Biodiversity. In Nature-Based Solutions to Climate Change Adaptation in Urban Areas_Linkages between Science, Policy and Practice; Kabisch, N., Korn, H., Stadler, J., Bonn, A., Eds.; Springer: Cham, Switzerland, 2017; pp. 159-185.

26. Braubach, M.; Egorov, A.; Mudu, P.; Wolf, T.; Ward Thompson, C.; Martuzzi, M. Effects of Urban Green Space on Environmental Health, Equity and Resilience. In Nature-Based Solutions to Climate Change Adaptation in Urban Areas-Linkages between Science, Policy and Practice; Kabisch, N., Korn, H., Stadler, J., Bonn, A., Eds.; Springer: Cham, Switzerland, 2017; pp. $187-206$.

27. Kabisch, N.; Annerstedt van den Bosch, M. Urban Green Spaces and the Potential for Health Improvement and Environmental Justice in a Changing Climate. In Nature-Based Solutions to Climate Change Adaptation in Urban Areas-Linkages between Science, Policy and Practice; Kabisch, N., Korn, H., Stadler, J., Bonn, A., Eds.; Springer: Cham, Switzerland, 2017; pp. $207-220$.

28. Haase, A. The Contribution of Nature-Based Solutions to Socially Inclusive Urban Development-Some Reflections from a Social-Environmental Perspective. In Nature-Based Solutions to Climate Change Adaptation in Urban Areas-Linkages between Science, Policy and Practice; Kabisch, N., Korn, H., Stadler, J., Bonn, A., Eds.; Springer: Cham, Switzerland, 2017; pp. $221-236$.

29. Wamsler, C.; Pauleit, S.; Zolch, T.; Schetke, S.; Mascarenhas, A. Mainstreaming Nature-Based Solutions for Climate Change Adaptation in Urban Governance and Planning. In Nature-Based Solutions to Climate Change Adaptation in Urban Areas-Linkages between Science, Policy and Practice; Kabisch, N., Korn, H., Stadler, J., Bonn, A., Eds.; Springer: Cham, Switzerland, 2017; pp. 257-274.

30. Droste, N.; Schröter-Schlaack, C.; Hansjürgens, B.; Zimmermann, H. Implementing Nature-Based Solutions in Urban Areas: Financing and Governance Aspects. In Nature-Based Solutions to Climate Change Adaptation in Urban Areas-Linkages between Science, Policy and Practice; Kabisch, N., Korn, H., Stadler, J., Bonn, A., Eds.; Springer: Cham, Switzerland, 2017 ; pp. $307-322$.

31. Lafortezza, R.; Chen, J.; van den Bosch, K.C.; Randrup, B.T. Nature-based solutions for resilient landscapes and cities. Environ. Res. 2018, 165, 431-441. [CrossRef]

32. Frantzeskaki, N. Seven lessons for planning nature-based solutions in cities. Environ. Sci. Policy 2019, 93, 101-111. [CrossRef]

33. Frantzeskaki, N.; McPhearson, T.; Collier, M.J.; Kendal, D.; Bulkeley, H.; Dumitru, A.; Pintér, L. Nature-Based Solutions for Urban Climate Change Adaptation: Linking Science, Policy, and Practice Communities for Evidence-Based Decision-Making. BioScience 2019, 69, 455-466. [CrossRef]

34. Randrup, B.T.; Buijs, A.; Konijnendijk, C.C.; Wild, T. Moving beyond the nature-based solutions discourse: Introducing naturebased thinking. Urban Ecosyst. 2020, 23, 919-926. [CrossRef]

35. Kabisch, N.; Frantzeskaki, N.; Pauleit, S.; Naumann, S.; Davis, M.; Artmann, M.; Bonn, A. Nature-based solutions to climate change mitigation and adaptation in urban areas: Perspectives on indicators, knowledge gaps, barriers, and opportunities for action. Ecol. Soc. 2016, 21, 39. [CrossRef]

36. Roggema, R. (Ed.) Contemporary Urban Design Thinking, Vol. 2, Nature Driven Urbanism; Springer: Dordrecht, The Netherlands, 2019.

37. Roggema, R. From Nature-Based to Nature-Driven: Landscape First for the Design of Moeder Zernike in Groningen. Sustainability 2021, 13, 2368. [CrossRef]

38. Pinnegar, S.; Randolph, B.; Troy, L. Decoupling growth from growth-dependent planning paradigms: Contesting prevailing urban renewal futures in Sydney, Australia. Urban Policy Res. 2020, 38, 321-337. [CrossRef]

39. Greater Sydney Commission. A Metropolis of Three Cities. Greater Sydney Region Plan-Connecting People; State Government of New South Wales: Sydney, Australia, 2018.

40. Australian Government and Government of NSW. Western Sydney City Deal. Vision. Partnership. Delivery. Sydney, Australia, 2018. Available online: https:/ / www.infrastructure.gov.au/cities / city-deals/western-sydney/files/western-sydney-city-deal pdf (accessed on 23 September 2019).

41. Benson, D.; Howell, J. Taken for Granted: The Bushland of Sydney and Its Suburbs; Kangaroo Press: Sydney, Australia, 1990.

42. Simpson, R.; Roggema, R. How to Design Sydney's Third City? In Contemporary Urban Design Thinking, Vol. 1, The Australian Approach; Roggema, R., Ed.; Springer: Dordrecht, The Netherlands, 2018; pp. 39-70.

43. Roggema, R. Landscape First! Nature-Driven Design for Sydney's Third City. In Contemporary Urban Design Thinking, Vol. 2, Nature Driven Urbanism; Roggema, R., Ed.; Springer: Dordrecht, The Netherlands, 2019; pp. 81-110. 
44. Yan, W.; Roggema, R. Developing a Design-Led Approach for the Food-Energy-Water Nexus in Cities. Urban Plan. 2019, 4, 123-138. [CrossRef]

45. Gill, S.E.; Handley, J.F.; Ennos, A.R.; Pauleit, S. Adapting cities for climate change: The role of the green infrastructure. Built Environ. 2007, 33, 115-133. [CrossRef]

46. Kambites, C.; Owen, S. Renewed prospects for green infrastructure planning in the UK. Plan. Pract. Res. 2006, 21, 483-496. [CrossRef]

47. Wu, J. Urban ecology and sustainability: The state-of-the-science and future directions. Landsc. Urban Plan. 2014, 125, $209-221$. [CrossRef]

48. Rebele, F. Urban ecology and special features of urban ecosystems. Glob. Ecol. Biogeogr. Lett. 1994, 4, 173-187. [CrossRef]

49. Alberti, M. Advances in Urban Ecology: Integrating Humans and Ecological Processes in Urban Ecosystems; No. 574.5268 A4; Springer: New York, NY, USA, 2008.

50. Peck, J.; Theodore, N.; Brenner, N. Neoliberal urbanism: Models, moments, mutations. Sais Rev. Int. Aff. 2009, 29 , 49-66. [CrossRef]

51. Theodore, N.; Peck, J.; Brenner, N. Neoliberal urbanism: Cities and the rule of markets. In The New Blackwell Companion to the City, 1625; Bridge, G., Watson, S., Eds.; Wiley: Hoboken, NY, USA, 2011.

52. Lewyn, M. Government Intervention and Suburban Sprawl: The Case for Market Urbanism; Springer/Palgrave Macmillan: New York, NY, USA, 2017.

53. Van den Berg, A.E.; Hartig, T.; Staats, H. Preference for nature in urbanized societies: Stress, restoration, and the pursuit of sustainability. J. Soc. Issues 2007, 63, 79-96. [CrossRef]

54. Bark, R.H.; Osgood, D.E.; Colby, B.G.; Halper, E.B. How do homebuyers value different types of green space? J. Agric. Resour. Econ. 2011, 395-415.

55. Keogh, G.; D’Arcy, E. Property market efficiency: An institutional economics perspective. Urban Stud. 1999, 36, 2401-2414. [CrossRef]

56. D'Arcy, E.; Keogh, G. Territorial competition and property market process: An exploratory analysis. Urban Stud. 1998, 35, 1215-1230. [CrossRef]

57. Evans, A.W. The property market: Ninety per cent efficient? Urban Stud. 1995, 32, 5-29. [CrossRef]

58. Gillham, O. The Limitless City: A Primer on the Urban Sprawl Debate; Island Press: Washington, DC, USA, 2002.

59. Harvey, R.O.; Clark, W.A. The nature and economics of urban sprawl. Land Econ. 1965, 41, 1-9. [CrossRef]

60. Peiser, R.B. Density and urban sprawl. Land Econ. 1989, 65, 193-204. [CrossRef]

61. Maddox, G. Oran Park, the Suburb that's Grown from a Population of 0 to 7500 in Eight Years. Sydney Morning Herald. 20 April 2018. Available online: https:/ / www.smh.com.au/national/nsw / oran-park-the-suburb-that-s-grown-from-a-population-of0-to-7500-in-eight-years-20180301-p4z2bb.html (accessed on 21 April 2018).

62. Department of Planning and Environment. Planning for Sydney's South West. Available online: https://www.planning.nsw.gov. au/Plans-for-your-area/Priority-Growth-Areas-and-Precincts/South-West-Growth-Area (accessed on 11 November 2020).

63. Epstein, L.H.; Paluch, R.A.; Roemmich, J.N.; Beecher, M.D. Family-based obesity treatment, then and now: Twenty-five years of pediatric obesity treatment. Health Psychol. 2007, 26, 381. [CrossRef]

64. Flouri, E.; Papachristou, E.; Midouhas, E. The role of neighborhood greenspace in children's spatial working memory. Br. J. Educ. Psychol. 2018, 89, 359-373. [CrossRef]

65. Li, D.; Sullivan, W. Impact of views to school landscapes on recovery from stress and mental fatigue. Landsc. Urban Plan. 2016, 148, 149-158. [CrossRef]

66. Mennis, J.; Mason, M.; Ambrus, A. Urban greenspace is associated with reduced psychological stress among adolescents: A geographic ecological momentary assessment (GEMA) analysis of activity space. Landsc. Urban Plan. 2018, 174, 1-9. [CrossRef] [PubMed]

67. Thompson, C.; Roe, J.; Aspinall, P.; Mitchell, R.; Clow, A.; Miller, D. More green space is linked to less stress in deprived communities: Evidence from salivary cortisol patterns. Landsc. Urban Plan. 2012, 105, 221-229. [CrossRef]

68. Mushi, M.; Shalala, R.; Young, J. Badgerys Urbanism; UTS School of Architecture: Sydney, Australia, 2017.

69. Calliari, E.; Staccione, A.; Mysiak, J. An assessment framework for climate-proof nature-based solutions. Sci. Total Environ. 2019, 656, 691-700. [CrossRef] [PubMed]

70. Raymond, C.M.; Frantzeskaki, N.; Kabisch, N.; Berry, P.; Breil, M.; Nita, M.R.; Geneletti, D.; Calfapietra, C. A framework for assessing and implementing the co-benefits of nature-based solutions in urban areas. Environ. Sci. Policy 2017, $77,15-24$. [CrossRef]

71. Almenar, J.B.; Elliot, T.; Rugani, B.; Philippe, B.; Gutiérrez, T.; Sonnemann, G.; Geneletti, D. Nexus between nature-based solutions, ecosystem services and urban challenges. Land Use Policy 2021, 100, 104898. [CrossRef]

72. Eggermont, H.; Balian, E.; Azevedo, J.M.N.; Beumer, V.; Brodin, T.; Claudet, J.; Fady, B.; Grube, M.; Keune, H.; Lamargque, P.; et al. Nature-based Solutions: New Influence for Environmental Management and Research in Europe. Gaia Ecol. Perspect. Sci. Soc. 2015, 24, 243-248. [CrossRef]

73. Roggema, R. Australian Urbanism; State of the Art. In The Australian Approach. Contemporary Urban Design Thinking; Roggema, R., Ed.; Springer: Dordrecht, The Netherlands, 2019; Volume 1, pp. 1-10.

74. McHarg, I.L. Design with Nature; Natural History Press: New York, NY, USA, 1969. 
75. Mostafavi, M.; Doherty, G. (Eds.) Ecological Urbanism; Lars Müller Publishers: Baden, Switzerland, 2010.

76. Waldheim, C. Landscape as Urbanism. A General Theory; Princeton University Press: Princeton, NJ, USA, 2016.

77. Kindon, S.; Pain, R.; Kesby, M. (Eds.) Participatory Action Research Approaches and Methods: Connecting People, Participation and Place; Routledge: London, UK, 2007; Volume 22.

78. McIntyre, A. Participatory Action Research; Sage Publications: Thousand Oakes, CA, USA, 2007; Volume 52.

79. Selener, J.D. Participatory Action Research and Social Change: Approaches and Critique; Cornell University: Ithaka, NY, USA, 1993.

80. De Jong, T.M. Kleine Methodologie voor Ontwerpend Onderzoek; BOOM Uitgevers: Amsterdam, The Netherlands, 1992.

81. Hauberg, J. Research by Design-A research strategy. Rev. Lusófona Arquit. Educ. Archit. Educ. J. 2011, 5, 46-56.

82. Milburn, L.-A.S.; Brown, R.D. The relationship between research and design in landscape architecture. Landsc. Urban Plan. 2003, 64, 47-66. [CrossRef]

83. Roggema, R. Research by Design: Proposition for a Methodological Approach. Urban Sci. 2016, 1, 2. [CrossRef]

84. Rosemann, J. The Conditions of Research by Design in Practice. In Proceedings of the Research by Design: International Conference Faculy of Architecture Delft University of Technology in Co-Operation with the EAASE/AEEA, Delft, The Netherlands, 1-3 November 2000; pp. 63-68.

85. Swann, C. Action Research and the Practice of Design. Des. Issues 2002, 18, 49-61. [CrossRef]

86. Conversano, I.; del Conte, L.; Mulder, I. Research through Design for accounting values in design. In Proceedings of the 4th Biennial Research through Design Conference, Delft, The Netherlands, 19-22 March 2019; pp. 1-16. [CrossRef]

87. Condon, P.M. Design Charrettes for Sustainable Communities; Island Press: Washington, DC, USA, 2008.

88. Lennertz, B.; Lutzenhiser, A. The Charrette Handbook. The Essential Guide for Accelerated Collaborative Community Planning; The American Planning Association: Chicago, IL, USA, 2006.

89. Roggema, R.; Martin, J.; Horne, R. Sharing the climate adaptive dream: The benefits of the charrette approach. In Proceedings of the ANZRSAI Conference, Canberra, Australia, 6-9 December 2011.

90. Roggema, R. (Ed.) The Design Charrette: Ways to Envision Sustainable Futures; Springer: Dordrecht, The Netherlands, 2013.

91. New South Wales National Parks and Wildlife Service. Interpretation Guidelines for the Native Vegetation Maps of the Cumberland Plain, Western Sydney; Final Edition; NPWS: Hurstville, NSW, Australia, 2002.

92. Schwarz, P. The Art of the Long View. Planning for the Future in San Uncertain World; Bantam Doubleday Dell Publishing Group Inc.: New York, NY, USA, 1991.

93. Fry, T. Design Futuring; University of New South Wales Press: Sydney, Australia, 2009; pp. 71-77.

94. Cornish, E. Futuring: The Exploration of the Future; World Future Society: Chicago, IL, USA, 2004.

95. Shipley, R.; Newkirk, R. Vision and visioning in planning: What do these terms really mean? Environ. Plan. B Plan. Des. 1999, 26, 573-591. [CrossRef]

96. Gaffikin, F.; Sterrett, K. New visions for old cities: The role of visioning in planning. Plan. Theory Pract. 2006, 7, 159-178. [CrossRef]

97. Roggema, R. Adaptation to climate change: Does spatial planning help? Swarm planning does! WIT Trans. Ecol. Environ. 2009, $127,161-172$.

98. Callon, M. Actor-Network Theory—The Market Test. Actor Network Theory and after; Law, J., Hassard, J., Eds.; Oxford University Press: Oxford, UK, 1999.

99. Bruno Latour, B. Reassembling the Social: An Introduction to Actor-Network-Theory; Oxford University Press: New York, NY, USA, 2005; 328p.

100. DeLanda, M. A New Philosophy of Society: Assemblage Theory and Social Complexity; Bloomsbury Publishing: London, UK, 2019.

101. Deleuze, G.; Guattari, F. A Thousand Plateaus; Athlone Press: London, UK, 1988.

102. DeLanda, M. Deleuzian social ontology and assemblage theory. In Deleuze and the Social; Edinburgh University Press: Edinburgh, UK, 2006; pp. 250-266.

103. Nowak, D.J. Institutionalizing urban forestry as a "biotechnology" to improve environmental quality. Urban For. Urban Green. 2006, 5, 93-100. [CrossRef]

104. Miller, R.W.; Hauer, R.J.; Werner, L.P. Urban Forestry: Planning and Managing Urban Greenspaces; Waveland Press: Long Grove, IL, USA, 2015.

105. Konijnendijk, C.C.; Ricard, R.M.; Kenney, A.; Randrup, T.B. Defining urban forestry-A comparative perspective of North America and Europe. Urban For. Urban Green. 2006, 4, 93-103. [CrossRef]

106. Park, H. A Model of Food Forestry and its Monitoring Framework in the Context of Ecological Restoration. Ph.D. Thesis, Pusan National University, Busan, Korea, 2016.

107. Park, H.; Kramer, M.; Rhemtulla, J.M. Urban Food Forestry: Current state and future perspectives. Urban For. Urban Green. 2019, 45,126482 .

108. Clark, K.H.; Nicholas, K.A. Introducing urban food forestry: A multifunctional approach to increase food security and provide ecosystem services. Landsc. Ecol. 2013, 28, 1649-1669. [CrossRef]

109. Bewsher Consulting PTY LTD. South Creek Floodplain Risk Management Study and Plan for the Liverpool Local Government Area; Final Report; Liverpool Council: Liverpool, Australia, 2004.

110. McLean, L.; Roggema, R. Planning for a Prosumer Future: Central Park case study. Urban Plan. 2019, 4, 172-186. [CrossRef] 
111. Ostrom, E.E.; Dietz, T.E.; Dolšak, N.E.; Stern, P.C.; Stonich, S.E.; Weber, E.U. The Drama of the Commons; National Academy Press: Washington, DC, USA, 2002.

112. GANSW. Connecting with Country; Draft; GANSW: Sydney, Australia, 2020.

113. NSW. Act of Parliament 1995, Threatened Species Conservation Act 1995, NSW Act of Parliament; Online Edition; State of New South Wales: Sydney, Australia, 1995.

114. Boland, D.J.; Brooker, M.I.H.; Chippendale, G.M.; McDonald, M.W. Forest Trees of Australia; CSIRO Publishing: Collingwood, VIC, Australia, 2006; p. 628.

115. Syncarpia Glomulifera. Available online: https://en.wikipedia.org/wiki/Syncarpia_glomulifera (accessed on 21 February 2021).

116. Elliot, R.W.; Jones, D.L.; Blake, T. Encyclopaedia of Australian Plants Suitable for Cultivation: Volume 9 Sp-Z; Lothian Press: Port Melbourne, VIC, Australia, 2010; p. 159.

117. Holmgren, D. Essence of Permaculture; Holmgren Design Services: Hepburn, Australia, 2007.

118. Steffensen, V. Fire Country, How Indigenous Fire Management Could Help Save Australia; Hardie Grant Publishing: Sydney, Australia, 2020.

119. Wright, J.S.; Fu, R.; Worden, J.R.; Chakraborty, S.; Clinton, N.E.; Risi, C.; Sun, Y.; Yin, L. Rainforest-initiated wet season onset. Proc. Natl. Acad. Sci. USA 2017, 114, 8481-8486. [CrossRef] [PubMed] 